\title{
Do Acquiring Firms Knowingly Pay Too Much for Target Firms? Evidence from Earnings Management in Member-Firm Mergers in Korean Business Groups
}

Jae Wook Jeong* and Gil S. Bae**

This version, January 2011

* Jeong is from the School of Business, Daejeon University, Daejeon, Korea, 300-716, phone: $+82-42-280-2268$, fax: +82-42-283-7171, e-mail: jiw0713@dju.ac.kr.

** Bae is from the School of Business, Korea University, Seoul, Korea, 136-701, phone: +82-2-3290-1951, fax: +822-925-4035, e-mail: gilbae@korea.ac.kr.

We benefited from comments by Sea-Jin Chang, Lee-Soek Hwang, Jun-Koo Kang, Judy Rayburn, and Katherine Schipper. We are grateful to Korea Investors Service for providing the data used in the study. Jeong and Bae acknowledge financial support from the Corporate Governance Center of Korea University and Korea University's Faculty Research Grant, respectively.

${ }^{* *}$ Corresponding author. Tel.: +82-2-3290-1951; gilbae@korea.ac.kr 


\title{
Do Acquiring Firms Knowingly Pay Too Much for Target Firms? Evidence from Earnings Management in Member-Firm Mergers in Korean Business Groups
}

\begin{abstract}
In a typical merger between the firms belonging to the same business group (member-firm mergers), the controlling shareholder's holdings in the target firm are more than twice those in the acquiring firm. This difference in the controlling owner's holdings in the acquiring firm and the target firm creates a strong incentive for the controlling owner to pay more for the target firm than the target firm is actually worth. We find that acquiring firms deflate earnings in order to increase the numbers of shares to be issued to the target firm's shareholders. Moreover, the level of earnings deflation is systematically related with the controlling owner's expected benefits measured in several different ways. We also find that the stock price reaction to member-firm merger announcements is negatively correlated with the pre-issue-period earnings deflation. Consistent with the argument that the primary motivation of a member-firm merger is the maximization of the controlling owner's benefit, post-merger performance in member-firm mergers is lower than that in independent firm mergers.
\end{abstract}

JEL: G34, G14

Keywords: Member-firm mergers; Independent firm mergers; Controlling shareholder; Earnings management; Overpayment 
There is well documented evidence that returns to bidding firms making acquisitions are either insignificant, or even negative (Dodd, 1980; Firth, 1980; Jensen and Rubak, 1983; Asquith, 1983; Bradley, Desai, and Kim, 1988; Roll, 1986; Andrade, Mitchell, and Stafford, 2001; Capron and Pistre, 2002). In addition, merged companies on average do not show improvements in their operations during the postmerger period (Haspeslagh and Jemison, 1991; Roll, 1988, Sirower, 1997).

At least two explanations are consistent with the negative merger announcement effect and the poor operating performance observed in the post-merger period. Roll (1986) argues that acquiring firms' managers are overly confident of their own ability owing to hubris, and thus systematically overestimate the benefits of corporate combinations. Consequently, they inadvertently pay too much for target firms. Whereas the hubris hypothesis predicts that acquiring firms will unknowingly overpay for acquisitions, Morck, Shleifer, and Vishny (1990) propose that acquiring firms' managers have an incentive to knowingly overpay for target firms, if they undertake corporate acquisitions in an attempt to pursue their own personal objectives as opposed to maximizing shareholder value. Based on market return analysis, they conclude that managerial objectives drive bad acquisitions, thereby implying that managers who make bad acquisitions systematically overpay for target firms.

In this study, we present evidence that the conflict of interest between the controlling owner and minority shareholders also results in systematic overpayment for target firms in certain mergers. Our investigation differs from studies predicated on the hubris hypothesis, as it deals with knowing overpayment. Our study also differs from that of Morck, Shleifter, and Vishny (1990), as it is based on the conflict of interest between the controlling owner and minority shareholders.

Mergers between member firms within business groups ${ }^{1}$ (henceforth, "member-firm mergers") in Korea are particularly appropriate to an examination of overpayment in mergers from the viewpoint of the

\footnotetext{
${ }^{1}$ Article 3 of the Korean Fair Trade Commission's The Regulation of Monopoly and Fair Trade defines a business group as a group of companies in which (1) the controlling shareholder and affiliated companies own $30 \%$ or more of the companies' shares or (2) the controlling shareholder can exercise dominant influence concerning their management.
} 
conflict of interest between the controlling owner and minority shareholders for two reasons. First, the Korean market is dominated by business groups ${ }^{2}$ (known as chaebols) that are controlled by a single ultimate owner, who has de facto control over practically all of the important decisions of the member firms in the group despite relatively low ownership via pyramidal or interlocking ownership structure among member firms (Bae, Kang, and Kim, 2002). ${ }^{3} \quad$ Second, as the controlling owner in the business group has diversified his operations into several different industries, business groups have several member firms, many of which are privately held. ${ }^{4}$ Given that business groups have many member firms, in which the controlling owner's holdings differ considerably, and that shareholder protection and corporate governance are inherently weak in Korea, ${ }^{5}$ controlling owners can readily undertake actions that benefit them personally at the cost of minority shareholders. One such mechanism is mergers between member firms within the business group.

From the controlling owner's viewpoint, two important features make stock-for-stock member-firm mergers a particularly attractive means for wealth transfer. ${ }^{6}$ First, because a member-firm merger would essentially allow for the controlling shareholder to exchange shares in the poorly performing target firm with shares in the well-performing acquiring firm, the controlling owner can combine a good acquiring firm and a bad target firm. In fact, in our sample, the operating performance of the acquiring firm is on average considerably higher than that of the target firm. Second, the average controlling shareholder's holdings in the target firm are twice those in the acquiring firm. Together, they provide a strong incentive for the controlling owner to engage in a stock-for-stock merger between member firms. Moreover, as the

2 In 2004, the Financial Supervisory Services (FSS) of Korea identified a total of 51 groups that are subject to governmental regulations. Together, these groups have 884 member firms (i.e., on average 17.3 member firms per group) and their total assets and net sales are 696,000 billion won and 627,000 billion won, respectively.

3 Although pyramidal ownership structures exist, interlocking ownership structures are more common in Korean business groups (Bae, Kang, and Kim, 2002).

${ }^{4}$ For example, the Samsung group, the largest group in Korea in terms of revenue, had 62 member firms in 2008 that operated in several different industries--including electronics, trading, retail, construction, shipbuilding, and services. Among 62 member firms, 17 (27\%) are listed and 45 (73\%) are unlisted, thereby indicating that the majority of the member firms are unlisted.

5 See Table 2 in La Porta, Lopez-de-Silanes, Shleifer, and Vishny (1998) for more details.

${ }^{6}$ Almost all mergers have been stock-for-stock mergers in Korea. In fact, we found no cash mergers during the sample period. 
controlling owner's holdings in the target firm are substantially higher than those in the acquiring firm, ${ }^{7}$ the controlling owner gains if the acquiring firm overpays for the target firm. The controlling owner, therefore, will have a strong incentive to make the acquiring firm overpay for the acquisition in an attempt to maximize personal gains from the merger.

In a stock-for-stock merger, overpayment means that the number of acquiring firm shares to be issued for a share of the target stock is too large. Hence, the agreed stock exchange ratio set in such a way that target shareholders receive more shares than the "fair" exchange ratio would suggest is essentially equivalent to systematic overpayment. If both the acquiring and target firms are listed companies, the exchange ratio is usually computed based on the acquiring and target firms' relative stock prices on or near the merger agreement date (Erickson and Wang, 1999). However, when the target firm is unlisted with no reliable market price, as is frequently the case in mergers between member firms within business groups, ${ }^{8}$ earnings-generating power and asset value are employed to calculate the stock exchange ratio. Recognizing the prominence of earnings in the determination of the exchange ratio, the controlling owner then has a strong incentive to manipulate earnings to influence the exchange ratio. Specifically, the systematic difference between the controlling shareholder's ownership in the acquiring firm and that in the target firm suggests that the acquiring firm will have a strong incentive to deflate earnings (to make it look bad) and the target firm to inflate earnings (to make it look good), thereby inflating the stock exchange ratio to the benefit of the controlling owner.

We find that acquiring firms deflate earnings, whereas target firms inflate earnings prior to stockfor-stock member-firm mergers. Moreover, earnings deflation by the acquiring firm is larger when the holdings of the controlling owner in the acquiring (target) firm are small (large). This finding is

\footnotetext{
${ }^{7}$ Specifically, the controlling shareholder's holdings in the acquiring firm are on average $27 \%$, but the controlling owner's holdings in the target firm are $65 \%$, according to our sample. Hence, overpayment by the acquiring firm for the merger by $\$ 1$ costs the controlling owner only 27 cents; however, the controlling owner gains 65 cents through his ownership in the target firm. Because the gains are twice as large as the losses from overpayment, the controlling owner clearly has a strong incentive to pay more for the acquisition.

${ }^{8}$ In our study, 127 target firms in 152 member firm mergers (83.5\%) are unlisted.
} 
equivalent to the interpretation that acquiring firms systematically overpay for target firms in member-firm mergers. Given that earnings management is a volitional activity, this phenomenon is tantamount to an intentional overpayment for the target firm. In contrast, consistent with the findings of prior studies (Erickson and Wang, 1999; Louis, 2004), acquiring firms in mergers between independent firms inflate earnings. More importantly, in member-firm mergers in which acquiring firms already own all of the target firm's shares prior to the merger (hence, no stock exchange will occur; we call this type of mergers "member-firm mergers with no stock exchange" to differentiate them from member-firm mergers in which a stock exchange does occur, which is referred to simply as "member-firm mergers" or "member-firm mergers with stock exchange" if this clarification is desired), we find that acquiring firms do not manage earnings in either direction. This provides compelling support to the interpretation that the earnings deflation observed in member-firm mergers involving stock exchanges does indeed represent a systematic effort to overpay for the target firm. We also find that the announcement effect is positive for the acquiring firms. One interpretation for this positive market reaction is that the market corrects the mispricing attributable to earnings deflation in the period preceding a stock merger announcement. Finally, both one-year and three-year post-merger long-run price performances in member-firm mergers are be significantly more negative than in independent firm mergers or in member-firm mergers with no stock exchange.

Our work contributes to the literature in several ways. First, we present evidence that the conflict of interest between controlling owners and minority shareholders also results in systematic overpayment for target firms in member-firm mergers. Given that this type of agency conflict is quite common in many countries around the world (La Porta, Lopez-de-Silanes, and Shleifer, 1999), our study provides additional insights into the sources of knowing overpayment in certain mergers. Our study also contributes to the literature on tunneling in that it delineates a precise means by which wealth transfers are effected; despite 
the claims that expropriation can be achieved via diverse means, ${ }^{9}$ relatively little is currently understood regarding the mechanisms by which expropriation is actually achieved. Specifically, our work expands Bae, Kang, and Kim (2002), who employ stock price reactions to merger announcements to infer that tunneling is the primary motivation for mergers in Korea; adding to their study, we provide evidence that acquiring firms manage earnings in order to knowingly overpay for target firms, and also that the level of earnings management is systematically related with the expected benefits accruing to the controlling owner from the merger.

The remainder of this study is structured as follows: In section 1, we review related studies and develop the testable implications; we then describe the research design and the sample in section 2; section 3 presents the empirical evidence; and section 4 concludes.

\section{Overpayments in Member-Firm Mergers and Hypothesis Development}

\subsection{Overpayment in member-firm mergers}

Prior studies have examined the possibility that bidders might overpay for target firms either inadvertently or knowingly in some mergers. Roll (1986) was the first to suggest that overconfident managers misjudge the benefit of acquisitions, thus resulting in inadvertent overpayment for target firms. Consistent with Roll's argument, Malmendier and Tate (2008) find that overly confident managers are more likely to conduct mergers, and that the market reaction is significantly more negative to takeover bids by overconfident managers.

While the hubris hypothesis predicts that acquiring firms unknowingly overpay for acquisitions, another perspective regarding overpayment is based on the agency conflicts between managers and shareholders (Jensen and Meckling, 1976; Fama, 1980; Fama and Jensen, 1983). From this viewpoint,

\footnotetext{
${ }^{9}$ For example, Johnson et al. (2000) argue that expropriations can be achieved through the sale of assets, goods, or services to the company through self-dealing transactions, by obtaining loans at preferential terms, by transferring assets from the listed companies to other companies under their control, or by diluting the interests of minority shareholders via the acquisition of additional shares at a preferential price.
} 
overpayment is the consequence of bidding firm managers' pursuit of personal objectives through acquisitions-If an acquisition is perceived to serve the personal objectives of the manager of the bidding firm, the manager will be willing to pay more for the target firm than it is worth to the bidding firms' shareholders in order to ensure that the merger occurs. Based on the finding that returns to bidding shareholders are lower when acquisitions are more likely to serve managers' personal benefits, Morck, Shleifer, and Vishny (1990) conclude that managerial objectives drive bad acquisitions. The implication is that managers who make bad acquisitions knowingly overpay for target firms. ${ }^{10}$

In this study, we propose that the conflict of interest between the controlling owner and minority shareholders also create a strong incentive for the acquiring firm to overpay for target firms in member-firm mergers. As such, although our work is similar to Morck, Shleifer, and Vishny (1990) in that it examines knowing overpayment in certain mergers, our study differs in an important way from Morck, Shleifer, and Vishny (1990) and Seyhun (1990) in that it deals with the conflict of interest between the controlling owner and minority shareholders.

Firms frequently operate as business groups in many countries, especially in emerging economies (Khanna and Palepu, 2000; Guillen, 2000; Khanna and Yafeh, 2005, 2007). Further, ownership are not separate from management in the majority of these countries (La Porta, Lopez-de-Silanes, and Shleifer, 1999), and concentrated ownership is also common (La Porta, Lopez-de-Silanes, and Shleifer, 1999; Claessens, Djankov, and Lang, 2000). Outside shareholder protection and corporate governance are also weak in most emerging economies (La Porta, Lopez-de-Silanes, and Shleifer, 1998). These constitute fertile ground for controlling owners to use member-firm mergers to their own benefit.

The ultimate owner already controls all the member firms operating as a business group, which renders any additional benefits accruing to the overall business group as the result of a member-firm merger

${ }^{10}$ Seyhun (1990) finds that top managers increase their net purchases prior to an acquisition, which is inconsistent with the notion that acquiring firms knowingly overpay for target firms. One interpretation of this conflicting finding is that there are on average no overpayments in acquisitions, but only in acquisitions that are driven by managerial objectives. 
not immediately apparent. That is, popular explanations for mergers, such as market power, operating or financial synergy, and market for corporate control (Bradley, Desai, and Kim, 1988; Seth, 1990; Chatterjee, 1992; Dodd and Ruback, 1977; Jensen and Ruback, 1983), are unlikely to be the principal reason for a member-firm merger. Rather, the conflict of interest between the controlling owner and the minority shareholders provides a compelling explanation for the motivations of member-firm mergers: Controlling owners, who control both the acquiring and target firms, employ mergers as a means to increase their personal wealth (Bae, Kang, and Kim, 2002). Consistent with this argument, the majority of mergers in Korea are mergers between member-firms belonging to the same business group. ${ }^{11} \quad$ Specifically, among 170 mergers in Korea that we identified between 1984 and 2004, $152(89.4 \%)$ are mergers between member firms within business groups.

Two observations regarding a typical member-firm merger support this argument. First, the controlling shareholder's holdings in the target firm are twice those in the acquiring firm. Second, the operating performance of the acquiring firm is higher than that of the target firm. Specifically, the average returns on assets of the acquiring and target firms are 0.19 and 0.02 , respectively, in the memberfirm mergers included in our sample. In short, the controlling owner has large holdings in a company (i.e., the target) that is performing poorly in the periods prior to the merger agreement, which creates a strong incentive for the controlling owner to engage in a stock-for-stock merger between the member firms in order to convert his shares in the poorly performing target firm to shares in the well-performing acquiring firm. More important for our research question, the more the acquiring firm pays for the target firm, the larger is the effect of the wealth transfer from minority shareholders of the acquiring firm to the controlling owner, providing the controlling owner with a strong incentive to pay more for the target firm.

11 Another reason for the dominance of member-firm mergers may be that hostile mergers and acquisitions were, until recently, virtually impossible due to regulations. It was not until 1994 that "open" hostile acquisitions first occurred in Korea. Since that time, approximately 10 or so mergers occur in a year, some of which are hostile acquisitions. Notwithstanding this, the majority of mergers in Korea are still friendly mergers. 


\subsection{Earnings management as a means to overpay in member-firm mergers}

Independent firms that are involved in a merger will act in their own best interests. This means that the acquiring firm will attempt to minimize the number of shares to issue, and the target firm will seek to maximize the number of acquiring firm shares to receive. As the total number of shares issued by the acquiring firm in a stock-for-stock merger is determined by a negotiated exchange ratio, both the acquiring and target firm have incentives to inflate earnings prior to a merger in order to influence the negotiated exchange ratio (Erickson and Wang, 1999; Louis, 2004). ${ }^{12}$ Consistent with this conjecture, Erickson and Wang (1999) and Louis (2004) find that the acquiring firm in a stock-for-stock merger overstates earnings in an effort to reduce the cost of purchasing the target. ${ }^{13}$

If the acquiring and target firms are independent of each other, this explanation is intuitive. This, however, is unlikely to apply to mergers between member-firms that are controlled by the same owner. When member-firms merge, the controlling owner trades his shares in the target firm for shares in the acquiring firm. Because the percentage of the controlling shareholder's holdings in the target firm is substantially larger than his holdings in the acquiring firm in a typical member-firm merger, it is obviously in the controlling owner's best interests to establish an exchange ratio that will enable him to receive as many shares of the acquiring firm as possible. Hence, the acquiring firm will have a strong incentive to overpay for the target firm (Jeong and Bae, 2006). In a stock-for-stock merger, overpayment essentially means that the number of acquiring firm shares to be issued for a share of target stock is too large. Specifically, if the agreed exchange ratio is established in such a way that the target shareholders receive more shares than the fair exchange ratio would indicate, the controlling owner overpays for the target firm.

If both the acquiring and target firms are listed companies, the exchange ratio between listed

12 Shivakumar (2000), Erickson and Wang (1999), and Louis (2004) argue that firms have incentives to inflate earnings even if the market is efficient: The acquirer will pay a higher price for the target if the acquirer does not manage earnings when the target expects it to do so.

13 Although Erickson and Wang (1999) find positive unexpected accruals for target firms in stock-for-stock mergers, these are not significant. They attribute the insignificance of the result to the timing of the acquisition, maintaining that the target firm is usually unaware of the potential buyout until the negotiation is initiated by the acquiring firm. 
companies is computed based on the acquiring and target firms' relative stock prices on or near the merger agreement date. ${ }^{14}$ However, the majority of target firms in member-firm mergers are unlisted with no reliable market value information available, ${ }^{15}$ which makes it impossible to use the relative stock prices to establish an appropriate exchange ratio. When the target firm is unlisted, with no reliable market price, the Korean Securities Issue and Disclosure Rule No. 82 specifies that the earnings-generating power and the asset value of the firm should be employed to calculate the exchange ratio. This suggests that earnings play a crucial role in establishing the exchange ratio in member-firm mergers. Recognizing the prominence of earnings in establishing the exchange ratio, the controlling owner has a strong incentive to deflate earnings in order to set the exchange ratio to his favor. Furthermore, because earnings deflation is clearly a conscious action by the acquiring firm, evidence of earnings deflation is equivalent to the acquiring firm's intentional overpayment in a member-firm merger. ${ }^{16}$

\subsection{Hypotheses}

In this study, we consider three different types of mergers: mergers between independent firms, member-firm mergers with no stock exchange, and member-firm mergers with a stock exchange.

14 Specifically, the exchange ratio between listed companies is determined by the average of the equally weighted averages of the closing prices of the month prior to the earlier of the dates of merger approval by the boards of directors or the date on which the merger contract is signed, the equally weighted averages of the closing prices of the week prior to the earlier of the dates of merger approval by the boards of directors, or the date on which the merger contract is signed, and the closing price of the earlier of the dates of merger approval by the boards of directors or the date on which the merger contract is signed. This price and the closing price of the earlier of the dates of merger approval by the boards of directors (or the date on which the merger contract is signed) are compared, and the lower of the two is used to calculate the exchange ratio (Korean Security Exchanges Law No. 190 and the Securities Issue and Disclosure Rule No. 82).

${ }^{15}$ Capron and Shen (2007) examine acquisitions of private firms. They, however, place their focus on the choice of the acquirer between public and private targets and the stock market reaction to the acquisition of private firms.

16 Such earnings management, of course, also entails costs. For example, if detected, the firm could suffer a loss of investor confidence and, possibly, be subject to regulatory intervention. Additionally, the firm could be sued (DuCharme, Malatesta, and Sefcik, 2004; Gong, Louis, and Sun, 2008) by investors. Notwithstanding, the controlling owner may perceive that the pursuit of self-interest via the manipulation of income in member-firm mergers poses little risk. First, financial reporting rules allow firms considerable discretion to adjust accruals to reflect business conditions. Second, accounting is opaque, and accounting irregularities are seldom challenged by outside shareholders in Korea. Bhattacharya, Daouk, and Welker (2003) report that the overall earnings opacity of Korea is the second highest among the countries examined. 
First, the acquiring firm in a merger between independent firms will attempt to minimize the number of shares to be issued. Thus, in this case, both the acquiring and target firms have incentives to inflate earnings. Second, in a merger between member firms in which the acquiring firm already owns all shares of the acquired firm prior to the merger, no stocks will be exchanged. As the controlling owner manipulates earnings to influence the stock exchange ratio, the acquiring and target firm will have no incentives to manage earnings in this type of merger. Finally, we consider member-firm mergers in which a stock exchange will occur. As the controlling owner gains from issuing more stocks for the target firm, the controlling owner will deflate the earnings of the acquiring firm and inflate the earnings of the target firm to maximize the benefits accruing from a member-firm merger. This prediction is formally described in our first hypothesis.

H1a: In mergers between independent firms, both the acquiring and target firms inflate earnings.

H1b: In mergers between member firms with no stock exchange, the acquiring and target firms do not manage earnings.

H1c: In mergers between member firms with a stock exchange, the acquiring firm deflates its earnings and the target firm inflates its earnings.

It is reasonable to expect that in H1c the controlling owner's incentive to manipulate the stock exchange ratio will be positively associated with the expected benefits from such a manipulation. Holding other things constant, the expected benefit is likely to be a function of the controlling owner's holdings in the acquiring and target firms and the size of the acquiring and target firms. Specifically, the controlling owner will benefit more from deflating earnings when his holdings in the acquiring firm are small and his holdings in the target firm are large. This suggests that earnings deflation in the acquiring firm will be 
more salient when the controlling shareholder's holdings in the acquiring firm are small and his holdings in the target firm are large. Arguably, what ultimately matters most might be the monetary value of the controlling owner's holdings in the acquiring and target firms. Because the monetary value of the controlling owner's holdings will be determined by the product of the shareholdings and the size of the firm, we expect that the product of these two factors is associated with the level of earnings management. ${ }^{17}$ To the extent that this argument is valid, the earnings deflation of the acquiring firm will be more salient when the product of the controlling owner's holdings and the size of the acquiring firm are small, and those in the target firm are large. Hence, we investigate the extent to which the expected benefits affect earnings management in our second hypothesis.

H2: In member-firm mergers involving a stock exchange, the magnitude of earnings management is positively associated with the expected benefit accruing from the earnings management.

Several studies find that average returns on an announcement of a merger between two independent firms are either insignificant or significantly negative. One interpretation of these observed negative returns from an earnings management perspective is that the negative returns represent a reversal of the stock price effects of the earnings inflation in the days leading up to the merger announcement (Erickson and Wang, 1999; Louis, 2004). Because acquiring firms overstate their earnings in the period preceding a stock merger announcement between two independent firms, realizing that its assessment of the firm is inflated, the market corrects the mispricing from the overstated earnings upon the announcement of the merger.

However, the market reaction to a merger announcement between member firms may be different. To the extent that the acquiring firm deflates earnings to inflate the exchange ratio in order to overpay for

17 Because the majority of the target firms in our study are unlisted, it is not possible to use the market prices, which are likely to be a superior proxy of the actual monetary value of the holdings. In this study, owing to the unavailability of the market values, we elected to use the book value (i.e., total assets - total debt). 
the target firm, and also that the analogous argument employed in Erickson and Wang (1999) and Louis (2004) remains valid, the market may react positively to the merger announcement, as it realizes that the acquiring firm is undervalued owing to the earnings deflation in the previous period. If investors correctly infer earnings deflation and undo the effects of earnings deflation on member-firm merger announcements, holding other things constant, member-firm merger announcements may result in an increase in the stock price.

It is unlikely that the previous period's earnings deflation is the sole determinant of the market reaction to a merger announcement. Although it may not be possible to completely rule out unidentified alternative explanations for the market reaction to merger announcements, we examine the relationship between the abnormal returns around member-firm merger announcements and the earnings management in year -1 to provide additional support to our interpretation of the market reaction to member-firm merger announcements. More specifically, if the abnormal returns around the member-firm merger announcements indeed represent the correction of the mispricing due to the earnings deflation in the premerger period, then the abnormal returns will be negatively correlated with the earnings management in year -1. This prediction is presented in our third hypothesis:

H3: Stock price reactions to merger announcements will be positive in member-firm mergers involving a stock exchange. Moreover, the abnormal returns around the member-firm merger announcements will be negatively correlated with the pre-merger-period earnings deflation.

If wealth transfers from minority shareholders to the controlling owner are the primary motivation underlying member-firm mergers, the controlling owner likely select a pair of firms in which the acquiring firm is "good" and the target firm is "bad," thus maximizing personal benefits to the controlling owner. If a good acquiring firm merges with a poor target firm, and moreover if the acquiring firm intentionally overpays for the target firm, then the performance of the merged company is likely to be lower in the post- 
merger period relative to that of the acquiring firm in the pre-merger period, and also that of the merged company consisting of two independent firms, as well as that of the merged company consisting of member-firms involving no stock exchange. Our final hypothesis is based on this rationale.

H4: Long-run post-merger stock price performance will be lower in member-firm mergers involving a stock exchange relative to that in mergers between independent firms and that in member-firm mergers with no stock exchange.

\section{The Sample and Research Method}

\subsection{The sample}

We collect comprehensive data on mergers occurring in Korea between 1981 and 2004 from three sources: the Korean Stock Exchange's Securities Daily, the Korea Stock and Futures website (kind.sm.krx.co.kr), and the Financial Supervisory Commission's Data Analysis, Retrieval, and Transfer System (dart.fss.or.kr). Merger terms are identified from the merger reports filed with the Fair Trade Commission (FTC). The FTC also annually identifies member firms for each business group on its website, and we identify member firm mergers and independent firm mergers based on this information.

Financial data for the acquiring firm and target firms are collected from the Korea Investors Service-Financial Analysis (KIS-FAS) and KIS-Value. The controlling owners' equity holdings are identified from the KIS-LINE, and the stock price data come from the Korea Investors Service-Stock Market Analysis Tool (KIS-SMAT). In order to calculate abnormal returns for merger announcements, the announcement date should be identified. The initial public announcement date is the date on which the acquiring firm files a merger report with the FTC. The initial public announcement dates for mergers are collected from the Securities Daily. If this date is not a trading day, we use the first trading day subsequent to this date. Target firm data is considerably more difficult to obtain, particularly for mergers occurring in the early part of the sample period, in part because the majority of the target firms in our 
sample are unlisted, and also because they disappear after the merger. In particular, information regarding controlling ownership in unlisted target firms is frequently unavailable, and this causes data attrition in the subsequent regression analysis.

Table 1, panel A presents the sample composition. In all, we identify 275 mergers occurring during the sample period. We exclude 87 cases in which the financial data or other data used in the study are missing or unavailable. This leaves us with 170 observations for which financial and other data for the acquiring firm are available. Among these, 18 (10.5\%) observations are mergers between independent firms. This relatively small number of mergers between independent firms indicates that mergers occurring during our sample period are predominantly between member firms of business groups. Among the 18 independent firm-mergers, the target firm is listed only in one case, suggesting that mergers in the open market were all but impossible in Korea in the sample period. There are 39 member-firm mergers in which the acquiring firm already owns all shares of the target firm prior to the merger, thus resulting in no stock exchange at the merger. In this type of member-firm mergers, all of the target firms are unlisted. Finally, there are 113 member-firm mergers in which a stock exchange occurs. Among those 113 mergers, target firms are listed in 25 cases $(22.1 \%)$ and unlisted in 88 cases $(77.9 \%)$, indicating that target firms are predominantly unlisted in this type of mergers as well.

Table 1, panel A also shows the number of observations for target firms for each type of merger corresponding to the acquiring firms. Table 1, panels B and $\mathrm{C}$ present the distribution of the acquiring and target firms across the year and industry, respectively. Panel B illustrates the higher frequency of mergers in the later years of our sample period. The majority of the firms in the sample are manufacturing firms, as shown in panel C.

Table 2 provides descriptive statistics for the acquiring and target firms in our sample. The average total assets of the acquiring (target) firms in mergers between independent firms are 766 (41) billion won, suggesting that the acquiring firm is almost 20 times as large as the target firm. Similarly, the acquiring firm in member-firm mergers with no stock exchange is substantially larger than the target firm. 
Although the difference in total assets is not as salient as is observed in the previous two groups, the acquiring firm in member-firm mergers involving a stock exchange is more than double of the target firm in terms of total assets. When size is defined alternatively using market value, book value, or revenues, this pattern remains unaffected.

Regardless of the type of mergers we examine, the average return on assets (ROA) of the acquiring firms is larger than that of the target firm. The difference between the operating performance of the acquiring and target firms, however, is largest in member-firm mergers involving a stock exchange. Specifically, in this type of merger, the average ROAs of the acquiring and target firms are 0.19 and 0.02 , respectively, suggesting that the controlling owners combine good acquiring firms and bad target firms.

The average shareholdings of the controlling owners in the acquiring firms are $25 \%, 30 \%$, and $27 \%$ in mergers between independent firms, in member-firm mergers with no stock exchange, and in memberfirm mergers involving a stock exchange, respectively. Although the controlling holdings in the target firm are $58 \%$ in mergers between independent firms, this controlling shareholder is not the same as that in the acquiring firm. There are no controlling holdings in member-firm mergers in which the acquiring firm owns all shares of the target firm prior to the merger; in this case, the acquiring firm is the sole shareholder in the target firm. Finally, the controlling holdings in the target firms are $65 \%$ in member-firm mergers involving a stock exchange.

\subsection{Measuring earnings management}

Earnings consist of not simply cash flows, but also the component referred to as accruals. Accruals are accounting adjustments to the firm's cash flows from operations consistent with financial reporting regulations. ${ }^{18}$ Accruals contain important information regarding the future earnings of the firm, and thus

18 See Appendix B of Teoh, Welch, and Wong (1998a) for a summary of the accrual adjustments permitted by generally accepted accounting principles. Some of these include credit sales and purchases, estimates for uncollectibles (bad debts), estimates for write-offs of inventory and fixed assets, and depreciation policies. Accrual adjustments are dependent on the firm/business environment and management's assessment, subject to independent 
they help to convey information that more closely approximates the firm's "true" economic performance that is not always reflected in the current cash flows. Financial reporting rules allow firms considerable discretion to adjust accruals to reflect business conditions. For example, firms have discretion over their choice of accounting methods, the estimates for the application of these methods, and the period during which these accruals must be made. Previous research has shown that accounting accruals are affected by agency issues and asymmetric information, and are thus subject to manipulation. ${ }^{19}$ If managers misrepresent the firm's performance through manipulation of accruals and investors are unable to see through this, accruals will contribute to distort the firm's future prospects.

The key variable, total accruals, measures the difference between net earnings and cash flows. If managers use discretion to influence market perceptions, we expect that "discretionary" accruals will systematically reflect managerial intentions. To measure discretionary accruals, we use the model developed by Jones (1991). This model is summarized in Appendix A. Essentially, total accruals are regressed on the difference of change in sales revenues and accounts receivable, and the levels of property, plant, and equipment. The cross-sectional regression is conducted for each fiscal year of the firms engaged in a merger, using all non-merger firms in the same two-digit industry code. The estimated coefficients on the difference of change in sales revenues and accounts receivable, and property, plant, and equipment are used to calculate the expected accruals for firms engaged in a merger. The excess accruals variable is the residual after subtracting the expected accruals from the total accruals. Kothari, Leone, and Wasley (2005) show that discretionary accruals adjusted for a performance-matched firm's discretionary accruals, in which the match is based on a firm's industry membership and return on assets, tend to be the best-specified measure of discretionary accruals across a wide variety of simulated event conditions. Following Kothari, Leone, and Wasley (2005), we subtract the discretionary accruals for a matching firm from those for a sample firm. We interpret matching firm controlled discretionary accruals as a proxy for

auditor approval, of the magnitude and timing of actual economic events.

19 Healy and Wahlen (1999) provide a comprehensive review of earnings management research. 
accruals manipulation.

\section{Empirical Results}

\subsection{Earnings management by acquiring and target firms}

\subsubsection{Univariate results}

Table 3, panel A presents discretionary accruals for the acquiring firms around member-firm mergers for years -2 to +2 . Although our primary interest rests with member-firm mergers in which the stocks of the acquiring firm and target firm are exchanged, the discretionary accruals of two control groups are presented and discussed first. The mean discretionary accruals of the acquiring firm in year -1 (i.e., one year prior to a merger) in mergers between independent firms are positive (0.096) and significant, consistent with the findings of Louis (2004) and Erickson and Wong (1999), as well as our hypothesis H1a. This indicates that the acquiring firm, acting in its best interest, attempts to minimize the number of shares to be issued to the shareholders in the target firm.

Next, we consider mergers between member firms in which the acquiring firm already owns all of the shares of the target firm. Although these are member-firm mergers within business groups, no stock exchange occurs in this type of merger. Hence, the controlling owner will have no incentive to manage earnings in this case. Consistent with the prediction in $\mathrm{H} 1 \mathrm{~b}$, the mean discretionary accruals for this type of merger in year -1 are insignificant.

More importantly, in member-firm mergers involving a stock exchange, the mean discretionary accruals for the acquiring firm in member-firm mergers in year -1 are -0.021 and significant at the 0.05 level. This shows that earnings management by the acquiring firm is negative and significant, consistent with the prediction in H1c that the acquiring firm deflates earnings to increase the stock exchange ratio such that the target firm receives more shares. It is worth noting that the deflation of earnings by the acquiring firm is precisely opposite of the observations made of mergers between independent firms, in 
which discretionary accruals are positive. ${ }^{20}$

Panel B of Table 3 presents the earnings management of target firms. ${ }^{21}$ The prediction regarding earnings management for target firms is less discriminating among different groups because target firms in both independent mergers and member-firm mergers are expected to increase earnings. Indeed, consistent with H1a, the discretionary accruals for the target firm in an independent merger are significantly positive in year -1 . The discretionary accruals of the target firm in a member-firm merger with no stock exchange, however, are insignificant. This is consistent with the prediction in H1b that these firms have no incentives to manipulate earnings. Consistent with the prediction in H1c, the mean (median) discretionary accruals in year -1 for target firms in member-firm mergers involving a stock exchange are $0.027(0.026)$ and significant.

Taken together, the univariate results in Table 3 provide support for the argument that the controlling owner in member-firm mergers manages earnings so as to intentionally overpay for target firms in pursuit of self-interest.

\subsubsection{Multivariate results}

Our focus in this study is on the pattern of earnings management in member-firm mergers involving stock exchanges. Hence, in this section, we provide the results of multivariate regression analysis using only member-firm mergers involving stock exchanges.

$\mathrm{H} 2$ predicts that the controlling owner's incentive to overpay for target firms will be salient when the benefit likely to accrue to the controlling owner is also larger. The benefit to the controlling owner is expected to be a function of the controlling owner's shareholdings in the acquiring and target firms, as well as the size of the acquiring and target firms. Specifically, we include the following variables in the

${ }^{20}$ Earnings management in years 0 and 1 for the acquiring firms has the opposite signs of those for year -1 . Since managed income should, in fact, reverse, this is not entirely unexpected.

${ }^{21}$ Because the target firm ceases to exist once merged with the acquiring firm, discretionary accruals can be calculated only up to year -1 . 
regression in an effort to measure the strength of the controlling owner's incentives to overpay, and therefore to manage earnings: (1) the controlling owner's holdings in the acquiring and target firms; (2) the product of the controlling owner's holdings in the acquiring firm and the size of the acquiring and target firms; (3) the ratio between the controlling owner's holdings in the acquiring and target firms; and (4) the ratio between the product of the controlling owner's holdings in the acquiring firm and the size of the acquiring firm and the product of the controlling owner's holdings in the target firm and the size of the target firm. We expect that the incentive of the controlling owner to deflate the acquiring firm's earnings should be associated with the above variables that are expected to proxy for the benefits accruing to the controlling owner from overpayment.

Regression results using the earnings management of the acquiring firm as dependent variable

Table 4 presents the results using the earnings management of the acquiring firm as dependent variable. The key experimental variables are the controlling owner's holdings in the acquiring firm (AHOLDING) and the target firm (THOLDING) (in regression (1)), the product of the controlling owner's holdings in and the size of the acquiring firm $(A H O L D I N G \times A S I Z E)$ and the target firm $(T H O L D I N G \times$ TSIZE) (in regression (2)), the ratio between the controlling owner's holdings in the acquiring and target firms (AHOLDING / THOLDING) (in regressions (3) and (4)), and the ratio between the product of the holdings of the controlling owner and the size of the acquiring and target firms $($ AHOLDING $\times$ ASIZE) $/$ $($ THOLDING $\times$ TSIZE) (in regressions (5) and (6)).

Also included in the model are the following control variables that are known to influence the firm's incentives to manage earnings: holdings by institutional shareholders (INSTITUTION); holdings by foreign shareholders (FOREIGN); ${ }^{22}$ cash flows from operations divided by total assets (COA); earnings divided by total assets $(R O A)$; and the debt-to-equity ratio (DEBT). Because both the acquiring and target ${ }^{22}$ Since most target firms are unlisted, they usually have no institutional and foreign holdings. Thus, these variables
are not included in the target firm characteristics. 
firm's characteristics are likely to influence the results, we include variables of both the acquiring and target firms simultaneously in the regression.

In regression (1), the coefficients on AHOLDING and THOLDING are 0.001 with a $t$-value of 2.53 and -0.001 with a $t$-value of -2.78 , respectively. This is consistent with $\mathrm{H} 2$ that the earnings deflation of the acquiring firm is positively (negatively) associated with the controlling owner's holdings in the acquiring (target) firm. This indicates that earnings deflation undertaken in order to inflate the stock exchange ratio to intentionally overpay for the target firm is larger when the expected benefits accruing from earnings deflation are also greater. In regression (2), the managerial incentives to overpay are measured by the holdings of the controlling owner multiplied by the firm size. In the regression, the coefficients on AHOLDING $\times$ ASIZE and THOLDING $\times$ TSIZE are 0.001 and -0.001 , respectively, both significant at the 0.01 level. This shows that that the earnings deflation of the acquiring firm is positively (negatively) associated with the product of the controlling shareholder's holdings and the size of the acquiring (target) firm, consistent with the prediction in $\mathrm{H} 2$.

It is possible that the relative ratio of the controlling owner's holdings in the acquiring and target firms influences the controlling owner's incentives to overpay for target firms in each acquisition. In order to assess this, we create a variable by dividing the controlling owner's holdings in the acquiring firm by those in the target firm, and replace the two separate holdings variables in regression (1) with this ratio in regressions (3) and (4). In this construction, the expected benefits from overpayment are likely to be large when the ratio is small. Hence, the controlling owner will have strong incentives to aggressively deflate the earnings of the acquiring firm if this ratio is small. Thus, a positive coefficient would be consistent with H2. In regressions (3) and (4), the coefficients on AHOLDING / THOLDING are 0.049 and 0.051 , respectively, and significant at the 0.01 level. This indicates that the earnings deflation of the acquiring firm is more pronounced when the expected benefits accruing to the controlling shareholder from the overpayment are also larger.

In regression (4), we add the large group dummy into the regression in order to determine whether 
intentional overpayment through earnings deflation is larger or smaller in larger business groups. ${ }^{23}$ On the one hand, larger groups tend to have more member firms and more complex operations, features which are likely to facilitate earnings management. On the other hand, they are also subject to greater scrutiny by the government and the media, which would make earnings management more difficult. Therefore, the net effect of these two conflicting forces remains an empirical issue. In regression (4), the coefficient on the LARGE dummy is 0.033 and significant at the 0.1 level, indicating that the level of earnings deflation is less in larger business groups. This finding is inconsistent with Bae, Kang, and Kim (2002), who conclude that the expropriation of minority shareholders is larger in the top 30 business groups in Korea. One reason for this discrepancy is that their inference is predicated on the market reaction whereas our finding is based on earnings management.

Finally, in regressions (5) and (6), the experimental variable is the ratio derived from dividing AHOLDING $\times$ ASIZE by THOLDING $\times$ TSIZE. The coefficients of this ratio are 0.054 and 0.055 , respectively, and significant at the 0.01 level. The positive coefficient shows that the acquiring firm deflates earnings more in order to induce overpayment when the expected benefits accruing to the controlling shareholder from overpayment are also larger. The coefficient on LARGE in regression (6) is not significant.

Regressions (3) to (6) show that the main conclusion is unaffected if the ratio of the holdings in the acquiring and target firms or the ratio of the product of the holding and firm size is used as a proxy variable for the controlling owner's incentive to overpay. Overall, our results provide strong support for the interpretation that acquiring firms knowingly overpay for target firms via earnings deflation in memberfirm mergers.

The signs of the coefficients of the control variables are generally consistent with this expectation. Specifically, the coefficient on COA is negative and significant, consistent with the findings of prior studies

23 The Korean Fair Trade Commission ranks business groups according to the size of their total assets and identifies the 30 largest business groups. These represent Korea's most prominent business groups. 
that cash flows and earnings management are negatively correlated. The coefficient on $R O A$ for acquiring firms is positive, likely representing the mechanical correlation between earnings and earnings management. Institutional investors and foreign investors are known to play an important role in governance. Consistent with this notion, the coefficient on FOREIGN is positive and significant at the 0.1 level, except in regression (6). This indicates that foreign investors contribute to reducing the earnings management of the acquiring firm, and thereby reduce intentional overpayments in related-firm mergers. However, the coefficient on INSTITUTION is not significant, suggesting that the role of the institutional investors is limited. $^{24}$

One concern in the above analysis is that the interaction of two continuous variables may be difficult to interpret. Also, although neither AHOLDING nor THOLDING in our sample is close to 0, nevertheless it remains possible that the ratio between them becomes either quite large or small in some cases. A potential solution to this problem could be centering the variables before running the regression. We use the median of each variable to center the variable. The regression results are presented in Table 4, panel B.

In regression (1), the coefficient on $D \_A H O L D I N G$ is not significant. However, in regression (2), the coefficient on D_THOLDING is -0.035 and significant at the 0.05 level. The significant negative coefficient on $D \_T H O L D I N G$ is consistent with the prediction in H2. In regression (3), the coefficient on D_AHOLDING/D_THOLDING is 0.037 and significant at the 0.05 level. This indicates that the finding in Panel A, Table 4 is not sensitive to the choice of either continuous or dummy variables. The results in regressions (4) and (5) provide a similar interpretation.

Regression results using the earnings management of the target firm as dependent variable

We now analyze the earnings management of the target firms. H2 predicts that the earnings

${ }^{24}$ Given the conflicting findings in prior studies (e.g., Agrawal and Knoeber, 1996; Chung, Firth, and Kim, 2002), this is not particularly surprising. 
inflation of the target firm should be positively associated with the expected benefits from such management. The key experimental variables are identical to those in Table 4 . Table 5 presents the regression results of the earnings management of target firms on the experimental and control variables.

In regression (1), the coefficient on AHOLDING and THOLDING is -0.001 with a t-value of -1.68 and 0.001 with a t-value of 2.34 , respectively. This is consistent with the prediction of $\mathrm{H} 2$ that earnings inflation by the target firm is negatively (positively) associated with the controlling owner's holdings in the acquiring (target) firm. In regression (2), the coefficients on AHOLDING $\times$ ASIZE and THOLDING $\times$ TSIZE are -0.001 with a $t$-value of -1.71 and 0.001 with a $t$-value of 2.50 , respectively, indicating that the results are insensitive to the choice of the proxy variable for the controlling shareholder's incentives. When the ratio of the controlling owner's holdings in the acquiring firm to those in the target firm replaces two separate holdings variables, a negative coefficient would be consistent with our prediction. In regressions (3) and (4), the sign of the coefficient on AHOLDING / THOLDING is negative as predicted, but not significant at the conventional level. Likewise, in regressions (5) and (6), the coefficient on the ratio obtained by dividing AHOLDING $\times$ ASIZE by THOLDING $\times$ TSIZE is negative, but also not significant. The coefficient on LARGE is not significant in models (4) and (6).

Overall, the findings in Tables 4 and 5, along with those in the univariate analysis, provide compelling and consistent evidence that the controlling owner intends to make the acquiring firm pay too much for target firms in member-firm mergers in order to maximize his benefits from the merger.

\subsection{The market reaction to merger announcements}

Table 6 shows the stock market reaction to announcements of the three different types of mergers. We use the market model to calculate the abnormal announcement price reaction. The market model parameters are estimated using days -200 to -20 prior to a merger announcement. First, the mean threeday $(-1,1)$ and five-day $(-2,2)$ cumulative abnormal returns (CARs) are insignificant for merger announcements between independent firms. This finding differs from Louis (2004) and Erickson and 
Wang (1999), who find a negative market reaction to merger announcements. However, the relatively small sample size of the mergers between independent firms in our study makes an interpretation of the results rather difficult. The mean $\operatorname{CAR}(-1,1)$ are also insignificant for announcements of member-firm mergers involving no stock exchange. Given that the earnings management of the acquiring firm is insignificant in this type of mergers, the insignificant CARs to the merger announcements are consistent with the interpretation that part of the market reaction to merger announcements represents the reversal of the stock price effects of earnings management in the days leading up to the merger announcement; because the acquiring firms did not manage their earnings in the period preceding a merger announcement between member firms with no stock exchange, no price correction occurs upon the announcement of the merger. To the extent that the acquiring firm deflates earnings to set the exchange ratio so as to overpay for the target firm in member-firm mergers involving stock exchanges, the market's reaction to the merger announcement will be positive, as the market realizes that the acquiring firm is undervalued because of the earnings deflation done in the previous period. Consistent with $\mathrm{H} 3$, the mean $\mathrm{CAR}(-1,1)$ and $\mathrm{CAR}(-2,2)$ for announcements of member-firm mergers with stock exchanges are both 0.018 , and significant at the 0.05 level.

If the price reaction to the member-firm merger announcement indeed represents the market's rational revision to correct for the downward mispricing of the prior period, the abnormal return around the member-firm merger announcements will be negatively correlated with the pre-merger-period earnings deflation. For example, using the CARs over the period from 21 days before to 1 day after the merger announcement, Louis (2004) reports a significant negative correlation between the earnings management and the cumulative abnormal return for acquirers. ${ }^{25}$ Shivakumar (2000) also finds a similar negative relation between the CARs over the two days surrounding the equity offering announcements and the abnormal accrual. Following these studies, we conduct regression analysis to further assess the validity of

${ }^{25}$ However, Louis (2004) finds no evidence of a significant inverse relationship between earnings management and abnormal returns over the three days around the merger announcements. 
the argument that part of the positive market reaction to a member-firm merger announcement represents the correction for the prior period's downward mispricing. Specifically, we regress CAR(-1, 1) around the merger announcement date on the earnings management in year -1 , along with control variables for member-firm mergers. Table 7 presents the multivariate regression results.

Consistent with the findings of univariate analysis in Table 6, the coefficients on EARNINGS MANAGEMENT are -0.374 with $t$-values of -3.88 and -0.449 with a $t$-value of -3.62 in regressions (1) and (2), respectively. This indicates that earnings management in the year preceding a merger announcement is negatively correlated with announcement period returns. The negative relationship between the announcement period CARs and the earnings management is consistent with Louis (2004) and Shivakumar (2000), and is also consistent with the interpretation that investors adjust the stock price at the merger announcement to correct for the mispricing from earnings deflation in the year preceding a member-firm

merger. Nevertheless, there is an important difference between our finding and that of Louis (2004) and Shivakumar (2000); whereas the negative relationship reported by Louis (2004) is from the earnings inflation in the premerger period and the negative announcement returns, the negative coefficient in our study is from earnings deflation in the pre-merger period and the positive announcement returns. No other variables in the model are significant. Overall, the results in Tables 6 and 7 together provide support to the interpretation that the positive market reaction to merger announcements that is observed both in our study and in Bae, Kang, and Kim (2002) represents the reversal of the pre-merger period mispricing.

\subsection{Post-merger abnormal long-run stock returns}

In this section, we assess the long-run abnormal price performance of the merged entities. As Barber and Lyon (1997) show that the matching-firm-controlled buy-and-hold abnormal returns (BHAR) have desirable properties, we follow their approach to calculate the long-run abnormal price performance. In particular, matching firms are found first by matching on size, and then by matching on the market-tobook ratio. More specifically, we first identify non-merger firms whose size is between $70 \%$ and $130 \%$ of 
the sample firm in year -1 . Then, of these size-matched firms, the firm with the closest market-to-book ratio is selected as the matching firm. We use monthly return data to calculate the matching firmcontrolled buy-and-hold returns.

Table 8 reports the results. The average $\operatorname{BHAR}(-12,-1)$ of the acquiring firm in mergers between independent firms during months $(-12,-1)$ (i.e., one year prior to the merger announcement) are -0.048 , but not significant, indicating that the acquiring firm in mergers between independent firms performs no better or worse than other comparable firms prior to the merger. The average $\operatorname{BHAR}(1,12)$ and $\operatorname{BHAR}(1,36)$ are 0.031 and -0.067 , respectively, and insignificant. This shows that the merged entities of independent firms do not significantly underperform in the post-merger period.

Next, we consider member-firm mergers involving no stock exchange. Although these are mergers between member firms within business groups, as previously noted, no exchange of stocks occurs in this type of merger. The average $\operatorname{BHAR}(-12,-1)$ of the acquiring firm are -0.037 , and insignificant, indicating that the acquiring firm in member-firm mergers involving no stock exchange performs not differently from comparable firms prior to the merger. The average post-merger $\operatorname{BHAR}(1,12)$ and BHAR $(1,36)$ are 0.023 and -0.178 , respectively, and statistically insignificant, which shows that these firms do not underperform in the post-merger period.

In member-firm mergers involving stock exchanges, however, the mean BHAR(-12, -1) of the acquiring firm are 0.390 and significant. This indicates that the market performance of the acquiring firm is unusually good prior to the merger. If the primary motivation of this type of merger is wealth transfers, it is reasonable to expect that the controlling owner would select a good acquiring firm among the firms under his control in the business group. The significantly positive premerger market performance of the acquiring firm is consistent with the argument that the controlling owner does select a good acquiring firm.

In contrast to the good performance in the pre-merger-period, however, the average market performance of the merged entity declines considerably after the merger: The mean and median postmerger-period performances are significantly negative. Specifically, the mean (median) BHAR $(1,12)$ of 
the acquiring firm in a related-firm merger are $-0.163(-0.059)$, and the mean is significant. The three-year post-merger-period performance declines further; the mean (median) $\operatorname{BHAR}(1,36)$ are $-0.307(-0.119)$, and significant. This post-merger long-run underperformance may be attributable to, at least, two reasons. First, given that the controlling owner selects a target firm with relatively poor operating performance in the period previous to the merger, the post-merger-period performance of the combined entity is likely to decline; if the market gradually impounds the implication of member-firm mergers, post-member-firm merger performances are likely to be negative. Second, the post-merger long-run underperformance can be attributable to the acquiring firm's intentional overpayment for the merger; if the acquiring firm overpays for the target, the stock price is likely to decline. Overall, the findings in Table 8 provide support to the argument that the primary motivation of the controlling owner to conduct member-firm mergers is the maximization of the owner's self-interest.

Although the investigation described in this section is similar to that in prior studies that have evaluated post-acquisition stock price performance, our interpretation of the findings differs from those studies. If - as we contend, and as the evidence thus far suggests — self-interest of the controlling owner is the primary motivation underlying member-firm mergers in business groups, controlling owners should have a strong incentive to select a pair of firms consisting of a good acquiring firm and a bad target firm in order to maximize the personal benefits accruing to them from the merger. Furthermore, if acquiring firms intentionally overpay for target firms, the performance of the merged companies is likely to decline in the post-merger period relative to that of acquiring firms in the pre-merger period and that of acquiring firms engaged in the two other types of mergers discussed herein.

\subsection{Additional issues and alternative explanations}

\subsubsection{Information asymmetry}

An important assumption in the analysis thus far is that no information asymmetry between the acquiring and the target firm exists. The logic behind this assumption is that because a single owner 
controls both the acquiring and the target firm, potential information asymmetry should not be an issue as ownership grants the owner the right to investigate the true value of the resources embedded in the target firm (Williamson, 1985). However, this is true only when the owner/manager can estimate the true value of the target firm with no bias; otherwise, ownership rights can only reduce the target managers' incentive to misrepresent the value of the firm, but cannot fully eliminate the evaluative uncertainty surrounding the value of the target. This is particularly true when the target firm is a privately held firm with significant intangible resources and when the synergy of combining two firms is difficult to evaluate ex ante. Indeed, the difficulty of evaluating a privately held target is attributable not only to the relative scarcity of public information regarding privately held firms, but also to the absence of an active and liquid stock market. For instance, stock prices in stock markets can incorporate heterogeneous information about assets, and offer performance information that cannot be extracted from the firm's current or future accounting data (Holmstrom and Tirole, 1993).

Although this argument may not explain the intentional earnings management, particularly earnings deflation by the acquiring firm that we document, it does bear important implications for examinations of the market reaction to merger announcements and the post-merger long-run price performance of the merged entity. Information asymmetry pertains especially to the examination of acquirer returns. For example, recent studies have shown that the most significant mergers and acquisition performance regularity is the acquirers' experience of negative abnormal returns in acquiring publicly traded firms, and positive abnormal returns in acquiring privately held firms (Chang, 1998; Fuller, Netter, and Stegemoller, 2002).

In order to gauge the extent to which information asymmetry affects the controlling owner's earnings management decision, the magnitude of the market's reaction to merger announcements, and the post-merger long-run performance, we take two approaches: (1) we split the sample into two groups according to the listing status of the target firm and recalculate Tables 3,6 , and 8 , based on univariate analysis; and (2) we include the listing status of the target firm dummy variable as an additional control in 
the regression analysis in Tables 4, 5, and 7. In the unreported results, none of the results in Tables 3, 6, and 8 are qualitatively altered when the sample is split by the listing status of the target firm. More specifically, the mean earnings deflation for the acquiring firm in member-firm mergers in which the target firm is listed and unlisted is -0.012 and -0.023 , respectively, and this difference is not significant. The mean earnings inflations of the target firms are 0.021 and 0.047 , respectively, and this difference is not significant. More importantly, the mean $\operatorname{CAR}(-1,1)$ for merger announcements between member firms when the target firm is listed and unlisted are 0.013 and 0.019 , respectively, and this difference is also not significant. Furthermore, the mean three-year post-merger-period performance $\operatorname{BHAR}(1,36)$ for memberfirm mergers in which the target firm is listed and unlisted are -0.126 and -0.334 , and this difference is not significant. Similarly, when the listing status dummy variable is included in the regression models as an additional control, the coefficients on the main experimental variables remain qualitatively the same. Although it may not be possible to completely rule out the alternative explanation of the results based on information asymmetry, it does appear that our results are unlikely to be driven mainly by information asymmetry.

\subsubsection{Synergy effects}

It is also possible that the market's assessment of the merger and post-merger performance are driven by potential synergy effects arising from the merger. Although investigating this is beyond the scope of our study, nevertheless, we do include two variables that are expected to proxy for the synergy effects in order to gain insights into this issue. Specifically, we include (1) the same industry dummy that takes one if both the acquiring and target firms are in the same industry and (2) the horizontal merger dummy that takes one if the merger is horizontal. The mean discretionary accruals for the acquiring firm in member-firm mergers where the acquiring and target firms are in different industries and the same industry are -0.022 and -0.021 , respectively, and the difference is not significant. In addition, the mean $\operatorname{CAR}(-1,1)$ for the announcement of member-firm mergers in which the acquiring and target firms are in 
different industries and the same industry are 0.010 and 0.022 , respectively, but this difference is also not significant. Finally, the mean three-year post-merger-period BHAR for member-firm mergers in which the acquiring and target firms are in the different and same industry are -0.434 and -0.084 , which are not significantly different. In unreported results, the coefficients on these dummy variables are insignificant in Tables 4, 5, and 7. In sum, the synergy effect from a merger does not appear to be the primary reason for the observed results.

\subsubsection{The effect of the 1997 economic crisis}

In the process of overcoming the 1997 Asian financial crisis, the Korean government has exerted substantial efforts to improve corporate governance and accounting. For example, the Korean government introduced mandatory combined financial statements for large business groups, and amended the Fair Trade Act to restrict cross-debt guarantees among group member firms. It also clarified the responsibilities and legal duties of board members, established a rule requiring a minimum number of non-executive directors for listed companies, and amended the legal framework for insolvency. It also required an audit committee for large firms. The Korean government also abolished the regulations that restricted foreign investors' investments in Korean firms after the crisis. Since that time, foreign investors became one of the most important constituents determining the stock prices of Korean firms. Overall, these efforts likely improved corporate governance that provides protection for minority shareholders. This suggests that the controlling owner's ability to expropriate minority shareholders via earnings deflation may have considerably decreased in the period following the crisis.

To assess the possibility that our results are driven primarily by the observations in the preeconomic crisis period, we replicate the tables using only the observations in the post-crisis period defined as 1999 and thereafter. In unreported results, we find that all of the key experimental variables remain qualitatively unaffected in the post-crisis period. This indicates that our findings are not driven by the precrisis period observations. 


\subsubsection{Overpayment and the positive market reaction to a merger announcement}

It might appear that the prediction based on the controlling owner's interest hypothesis is inconsistent with the observed average positive market reaction to a member-firm merger announcement; if the self-interest is the principal motivation for member-firm mergers, and if the market understands this, then one might argue that the reaction to a merger announcement should be negative. The market, however, reacts positively to a member-firm merger announcement. There are two explanations for this positive market reaction. First, as we have already pointed out, realizing that the reported earnings in year -1 is understated, the market rationally revises the stock price at the merger announcement in order to correct for the downward mispricing of the previous period. This results in an increase in the stock price. The finding that the market reaction to merger announcements is negatively associated with prior period earnings management is consistent with the interpretation that at least some part of the market reaction is attributable to the reversal of the mispricing of the prior period due to earnings management. An alternative explanation for the observed positive market reaction is that the market somehow perceives that the merger will still prove beneficial, despite the strong incentives of the controlling shareholder's pursuit of his personal benefits in a member-firm merger. Regardless, the interpretation of our results-earnings deflation of the acquiring firm-is unlikely to depend upon the market reaction to merger announcements. The key finding of our study is that acquiring firms pay more than necessary for target firms through earnings deflation, which remains unaffected by the positive announcement market reaction.

\section{Summary and Conclusions}

The conflicts-of-interest between the controlling owner and minority shareholders hypothesis predicts that acquiring firms in member-firm mergers will have a strong incentive to overpay for target firms in member-firm mergers. Furthermore, the incentive of the acquiring firm to overpay for the target firm will be more salient when the expected benefits accruing from the overpayment are also larger. 
Consistent with this prediction, we find that acquiring firms in the member-firm merger deflate earnings in the year immediately prior to the merger. The results also indicate that the earnings deflation by the acquiring firms is systematically related with the benefits expected by controlling owners from such earnings deflation. To the extent that the observed earnings deflation leads to an inflated stock exchange ratio, this finding is consistent with the interpretation that controlling owners knowingly pay too much for target firms because doing so serve their personal objectives. The results of the analysis using the target firm earnings management lead to a similar conclusion. We also find that stock market reaction to a member-firm merger announcement is positive, consistent with the interpretation that the market reaction to merger announcements partly reflects the reversal of the stock price effects caused by earnings management in the days leading up to the merger announcement. The post-merger long-run price performance of the merged entities in the member-firm merger involving a stock exchange is considerably lower than that in mergers between independent firms or in member-firm mergers involving no stock exchange.

Our finding provides evidence that controlling owners employ member-firm mergers as a means to serve their personal benefits at the expense of minority shareholders of the acquiring firm. Our finding also indicates that the controlling owner achieves this by managing the earnings of the acquiring and target firms under his control. To the extent that the earnings deflation leads to an increase in the number of shares to be issued in the merger, our finding suggests that intentional overpayment indeed occurs in certain mergers. Our methodology of using earnings management to uncover the hypothesized knowing overpayment has an advantage over studies that rely on stock market reaction to merger announcements; since earnings management is a volitional decision, it is tantamount to knowing overpayment for the target firm. Because business groups are fairly common (Khanna and Yafeh, 2005, 2007; Khanna and Palepu, 2000; Guillen, 2000) and a concentrated ownership structure is also common around the world (La Porta, Lopez-de-Silanes, and Shleifer, 1999; Classens, Djankov, and Lang, 2000), our finding provides additional insights into the sources of knowing overpayment in certain mergers. 


\section{References}

Agrawal, A., and C. Knoeber. 1996. Firm performance and mechanisms to control agency problems between managers and shareholders. Journal of Financial and Quantitative Analysis 3: 377-397.

Andrade, G., M. Mitchell, and E. Stafford. 2001. New evidence and perspectives on mergers? Journal of Economic Perspectives 15: 103-120.

Asquith, P. 1983. Merger bids, uncertainty, and stockholder returns. Journal of Financial Economics 11: 51-83.

Bae, K., J. Kang, and J. Kim. 2002. Tunneling or value added? Evidence from mergers by Korean business groups. Journal of Finance 62: 2695-2740.

Baek, J., J. Kang, and K. Park. 2002. Corporate governance and firm value: evidence from the Korean financial crisis. Journal of Financial Economics 71: 265-313.

Bhattacharya, U., H. Daouk, and M. Welker. 2003. The world price of earnings opacity. The Accounting Review 78: 641-678.

Barber, B., and J. Lyon. 1997. Detecting long-run abnormal stock returns: the empirical power and specifications of test statistics. Journal of Financial Economics 43: 341-372.

Bradley, M., A. Desai, and E. Kim. 1988. Synergistic gains from corporate acquisition and their division between the shareholders of target and acquiring firms. Journal of Financial Economics 34: 3-39.

Capron, L., and N. Pistre. 2002. When do acquirers earn abnormal returns? Strategic Management Journal 23: 781-794.

Capron, L., and J. Shen. 2007. Acquisitions of private vs. public firms: private information, target selection, and acquirer returns. Strategic Management Journal 28: 891-911.

Chang, S. 1998. Takeovers of privately held targets, method of payment, and bidder returns. The Journal of Finance 53: 773-784.

Chatterjee, S. 1992. Source of value in takeover: synergy or restructuring-implications for target and bidder firms. Strategic Management Journal 13: 267-286.

Chung, R., M. Firth, and J. Kim. 2002. Institutional monitoring and opportunistic earnings management. Journal of Corporate Finance 8: 22-48.

Claessens, S., S. Djankov, and L. Lang. 2000. The separation of ownership and control in East Asian corporations. Journal of Financial Economics 58: 81-112.

DeCharme, L., P. Malatesta, and S. Sefcik. 2004. Earnings management, stock issues, and shareholder lawsuits. Journal of Financial Economics 71:27-40.

Dechow, P., R. Sloan, and A. Sweeney. 1995. Detecting earnings management. The Accounting Review 70: 
$193-225$.

Dodd, P. 1980. Merger proposals, managerial discretion and stockholder wealth. Journal of Financial Economics 8: 105-138.

Dodd, P., R. Ruback. 1977. Tender offers and stockholder returns: an empirical analysis. Journal of Financial Economics 5: 351-374.

Erickson, M., and S. Wang. 1999. Earnings management by acquiring firms in stock for stock mergers. Journal of Accounting and Economics 27: 149-176.

Fama, E. F. 1980. Agency problems and the theory of the firm. Journal of Political Economy 88: 288-307.

Fama, E.F., and M.C. Jensen. 1983. The separation of ownership and control. Journal of Law and Economics 26: 301-325.

Firth, M. 1980. Takeovers, shareholder returns and the theory of the firm. Quarterly Journal of Economics 94: $235-260$.

Fuller, K., J. Netter, and M. Stegemoller. 2002. What do returns to acquiring firms tell us? Evidence from firms that make many acquisitions. The Journal of Finance 67: 1763-1793.

Gaver, J., K. Gaver, and J. Austin. 1995, Additional evidence on bonus plans and income management, Journal of Accounting and Economics 19: 3-28.

Gong, G., H. Louis, and A. X. Sun. 2008. Earnings management and firm performance following openmarket repurchases. Journal of Finance 63: 947-966.

Guillen, M. 2000. Business groups in emerging economies: a resource-based view. Academy of Management Journal 43: 362-380.

Haspeslagh, P., D. Jemison. 1991. Managing acquisitions: creating value through corporate renewal. New York: Free Press.

Hayward M., and D. Jambrick. 1997. Explaining the premiums paid for large acquisitions: evidence of CEO hubris. Administrative Science Quarterly 42: 103-127.

Healy, P., and J. Wahlen, 1999. A review of the earnings management literature and its implications for standard setting. Accounting Horizon 13: 365-384.

Holmstrom, B., and J. Tirole. 1993. Market Liquidity and Performance Monitoring. The Journal of Political Economy 101: 678-709.

Jensen, M., and W. Meckling. 1976. Theory of the firm: managerial behavior, agency costs and ownership structure. Journal of Financial Economics 3: 335-360.

Jensen, M., and R. Ruback. 1983. The market for corporate control. Journal of Financial Economics 16: 373-388.

Jeong, J., and G. Bae. 2006. Earnings management by acquiring and target firms in related firm mergers. 
The Korean Accounting Review 31: 57-88 [printed in Korean].

Johnson, S., P. Boone, A. Breach, and E. Friedman. 2000. Corporate governance in the Asian financial crisis 1997-98. Journal of Financial Economics 58: 141-186.

Jones, J. 1991. Earnings management during import relief investigations. Journal of Accounting Research 29: 193-228.

Khanna, T., and K. Palepu. 2000. Is group membership profitable in emerging markets? An analysis of diversified Indian business groups. Journal of Finance 55: 867-891.

Khanna, T., and Y. Yafeh 2005. Business groups and risk sharing around the world. Working paper.

Khanna, T., and Y. Yafeh. 2007. Business groups in emerging markets: paragons or parasites? Journal of Economic Literature 45: 331-372.

Kothari, S., A. Leone, and C. Wasley. 2005. Performance matched discretionary accrual measures. Journal of Accounting and Economics 39, 163-197.

La Porta, R., F. Lopez-de-Silanes, and A. Shleifer. 1999. Corporate ownership around the world. The Journal of Finance 54, 471-517.

La Porta, R., F. Lopez-de-Silanes, A. Shleifer, and R. Vishny. 1998. Law and finance. Journal of Political Economy 106, 1113-1155.

Louis, H. 2004. Earnings management and market performance of acquiring firms. Journal of Financial Economics 74, 121-148.

Malmendier, U., and G. Tate. 2008. Who makes acquisitions? CEO overconfidence and the market's reaction. Journal of Financial Economics, forthcoming.

Morck, R., A. Shleifer, and R. Vishny. 1990. Do managerial objectives drive bad acquisitions? The Journal of Finance 45, 31-48.

Roll, R. 1986. The hubris hypothesis of corporate takeover. Journal of Business 59, 197-216.

Roll, R. 1988. Empirical evidence on takeover activity and shareholder wealth. In Knights, raiders, and targets: the impact of the hostile takeover. Coffee, Lowenstein, and Rose-Ackerman (eds). Oxford University Press: New York, 241-252.

Seth, A. 1990. Value creation in acquisitions: a re-examination of performance issues. Strategic Management Journal 11, 99-115.

Seyhun, H. 1990. Do bidder managers knowingly pay too much for target firms? Journal of Business 63, 439-464.

Shivakumar, L. 2000. Do firms mislead investors by overstating earnings before seasoned equity offering? Journal of Accounting and Economics 29, 339-371.

Shleifer, A., and R. Vishny. 1997. A survey of corporate governance. The Journal of Finance 52, 737-783. 
Sirower, M. 1997. The synergy trap: how companies lose the acquisition game. New York: The Free Press.

Sloan, R. 1996. Do stock prices fully reflect information in accruals and cash flows about future earnings? The Accounting Review 77, 289-315.

Teoh, S. H., I. Welch, and T. J. Wong. 1998. Earnings management and the long-run market performance of initial public offerings. The Journal of Finance 53, 1935-1974.

Williamson, O. 1985. The economic institutions of capitalism: Firms, markets, relational contracting. New York: The Free Press. 
Table 1

Mergers in the $1981-2004$ periods

Panel A: Distribution of merger activities by merger type

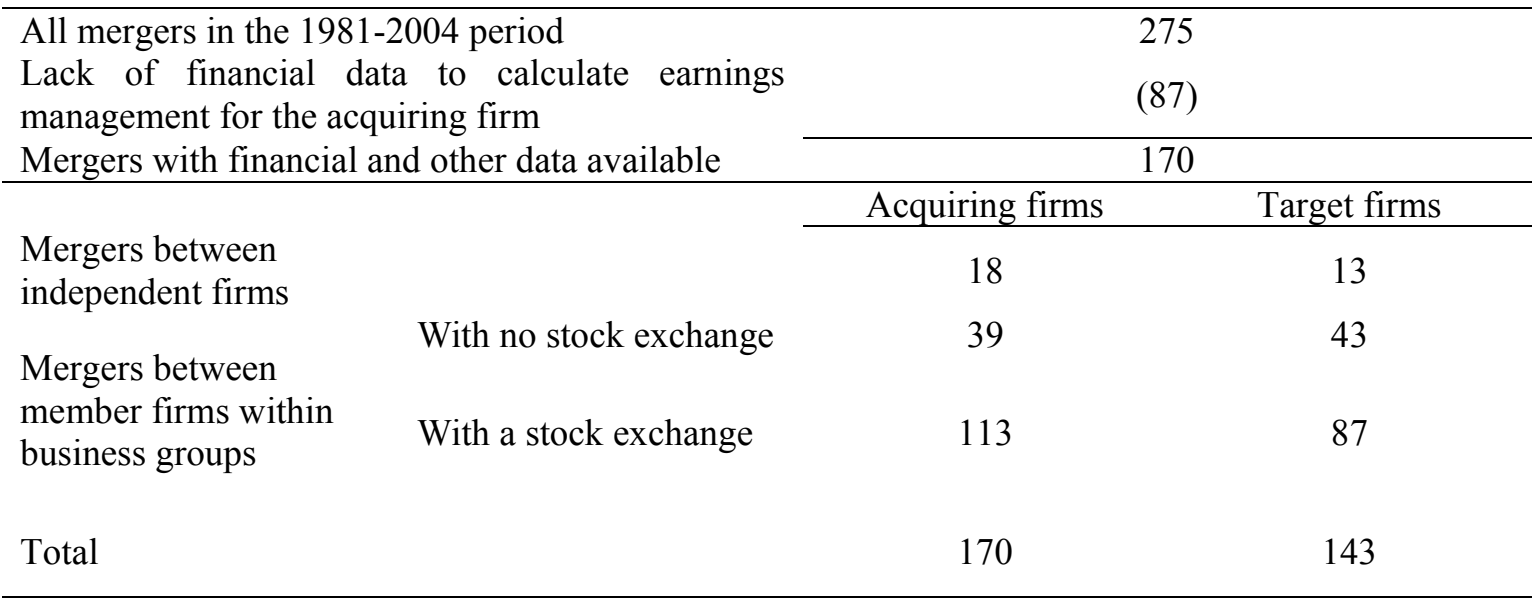

Panel B: Distribution of merger activities by merger type and period

\begin{tabular}{|c|c|c|c|c|c|c|}
\hline \multirow[b]{3}{*}{ Period } & \multicolumn{3}{|c|}{ Acquiring firms } & \multicolumn{3}{|c|}{ Target firms } \\
\hline & \multirow{2}{*}{$\begin{array}{c}\text { Mergers } \\
\text { between } \\
\text { independent } \\
\text { firms }\end{array}$} & \multicolumn{2}{|c|}{$\begin{array}{l}\text { Mergers between } \\
\text { member firms }\end{array}$} & \multirow{2}{*}{$\begin{array}{l}\text { Mergers } \\
\text { between } \\
\text { independent } \\
\text { firms }\end{array}$} & \multicolumn{2}{|c|}{$\begin{array}{l}\text { Mergers between } \\
\text { member firms }\end{array}$} \\
\hline & & $\begin{array}{c}\text { With no } \\
\text { stock } \\
\text { exchange }\end{array}$ & $\begin{array}{c}\text { With a } \\
\text { stock } \\
\text { exchange }\end{array}$ & & $\begin{array}{c}\text { With no } \\
\text { stock } \\
\text { exchange }\end{array}$ & $\begin{array}{c}\text { With a } \\
\text { stock } \\
\text { exchange }\end{array}$ \\
\hline $1981-1985$ & 2 & 0 & 14 & 0 & 0 & 0 \\
\hline 1986-1990 & 0 & 2 & 13 & 0 & 2 & 0 \\
\hline 1991-1995 & 5 & 10 & 21 & 2 & 10 & 6 \\
\hline $1996-2000$ & 3 & 7 & 32 & 3 & 8 & 60 \\
\hline 2001-2004 & 9 & 20 & 27 & 8 & 23 & 31 \\
\hline Total & 18 & 39 & 113 & 13 & 43 & 87 \\
\hline
\end{tabular}




\begin{tabular}{|c|c|c|c|c|c|c|}
\hline \multicolumn{7}{|c|}{ Panel C: Distribution of merger activities by industry } \\
\hline \multirow{3}{*}{ Industry } & \multicolumn{3}{|c|}{ Acquiring firms } & \multicolumn{3}{|c|}{ Target firms } \\
\hline & \multirow{2}{*}{$\begin{array}{l}\text { Mergers } \\
\text { between } \\
\text { independent } \\
\text { firms }\end{array}$} & \multicolumn{2}{|c|}{$\begin{array}{l}\text { Mergers between } \\
\text { member firms }\end{array}$} & \multirow{2}{*}{$\begin{array}{c}\text { Mergers } \\
\text { between } \\
\text { independent } \\
\text { firms }\end{array}$} & \multicolumn{2}{|c|}{$\begin{array}{l}\text { Mergers between } \\
\text { member firms }\end{array}$} \\
\hline & & $\begin{array}{c}\text { With no } \\
\text { stock } \\
\text { exchange }\end{array}$ & $\begin{array}{c}\text { With a } \\
\text { stock } \\
\text { exchange }\end{array}$ & & $\begin{array}{c}\text { With no } \\
\text { stock } \\
\text { exchange }\end{array}$ & $\begin{array}{l}\text { With a } \\
\text { stock } \\
\text { exchange }\end{array}$ \\
\hline Manufacturing & 12 & 32 & 89 & 7 & 32 & 53 \\
\hline Communication & 0 & 0 & 2 & 0 & 0 & 2 \\
\hline Construction & 3 & 3 & 11 & 1 & 2 & 10 \\
\hline Distribution & 1 & 2 & 6 & 1 & 4 & 14 \\
\hline Service & 2 & 2 & 5 & 4 & 5 & 8 \\
\hline Total & 18 & 39 & 113 & 13 & 43 & 87 \\
\hline
\end{tabular}


Table 2

Descriptive statistics of acquiring and target firms

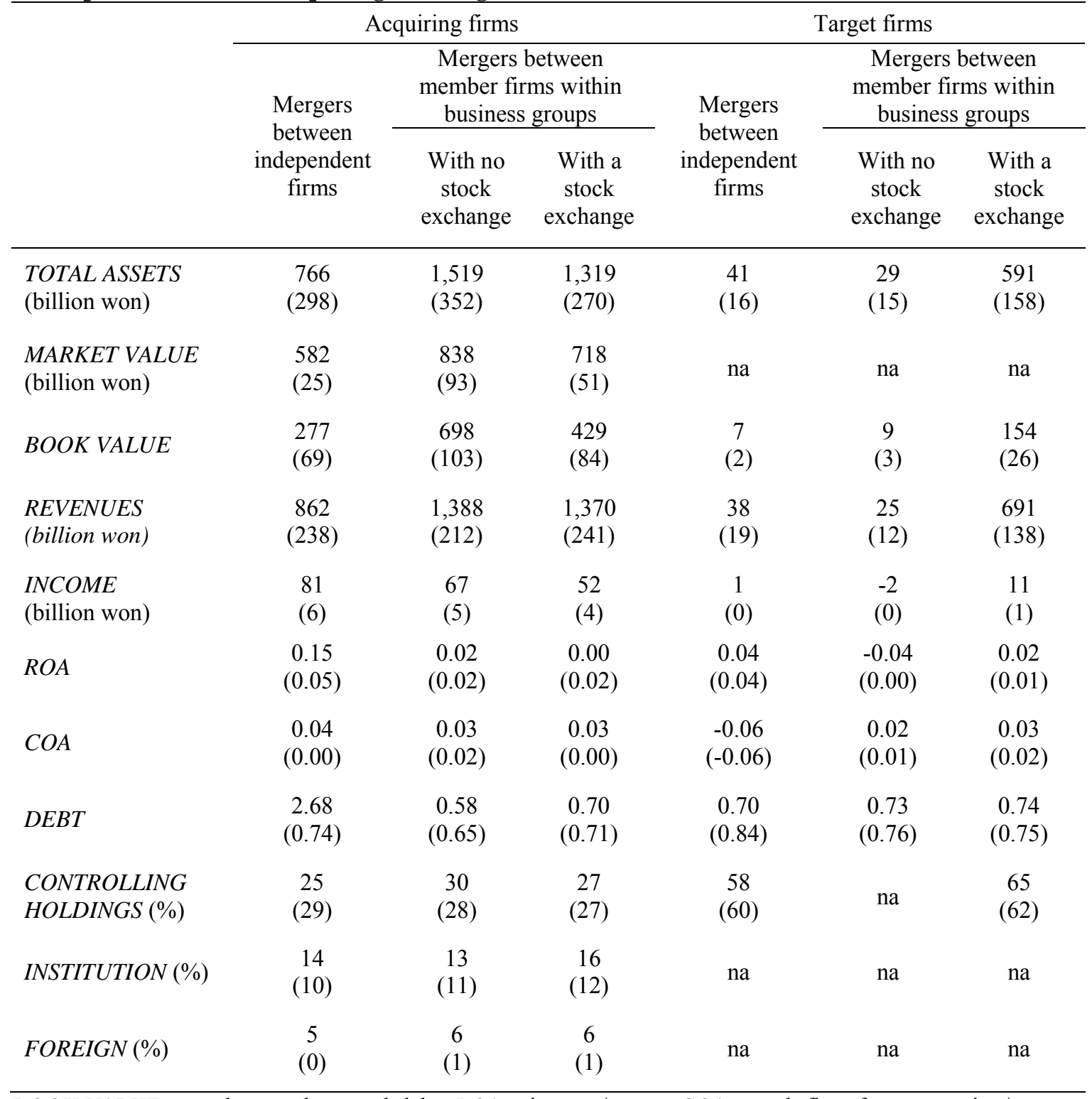

BOOK VALUE = total assets less total debt; ROA = income/assets; $C O A=$ cash flow from operation/assets; $D E B T=$ debt/assets; CONTROLLING HOLDINGS = the controlling owner's holdings; INSTITUTION = holdings by financial institutions; FOREIGN = holdings by foreign investors. All variables are estimated in year $t$-1 (i.e., one year prior to the merger announcement). Most target firms are unlisted with no reliable stock price data to calculate the market value. 
Table 3

Earnings management of acquiring and target firms around merger by merger type

Panel A: Acquiring firm earnings management (percentage of total assets)

\begin{tabular}{cccc}
\hline \multirow{2}{*}{ Year } & Mergers between & \multicolumn{2}{c}{$\begin{array}{c}\text { Mergers between mer firms within business } \\
\text { independent firms }\end{array}$} \\
\cline { 3 - 4 } & & With no stock exchange & With a stock exchange \\
\hline \multirow{2}{*}{-2} & -0.041 & 0.043 & 0.013 \\
& $(0.012)$ & $(0.008)$ & $\left(0.011^{* *}\right)$ \\
-1 & $0.096^{* * *}$ & 0.010 & $-0.021^{* *}$ \\
& $\left(0.077^{* * *}\right)$ & $(-0.007)$ & $\left(-0.004^{*}\right)$ \\
0 & -0.034 & -0.003 & $0.023^{* *}$ \\
& $(-0.001)$ & $(0.010)$ & $\left(0.006^{* *}\right)$ \\
1 & -0.039 & 0.035 & 0.010 \\
& $(-0.023)$ & $(0.013)$ & $0.003)$ \\
2 & -0.014 & 0.018 & $(0.001)$ \\
& $(0.001)$ & $(0.014)$ & 113 \\
\hline
\end{tabular}

Panel B: Target firm earnings management (percentage of total assets)

\begin{tabular}{|c|c|c|c|}
\hline \multirow{2}{*}{ Year } & \multirow{2}{*}{$\begin{array}{l}\text { Mergers between } \\
\text { independent firms }\end{array}$} & \multicolumn{2}{|c|}{$\begin{array}{c}\text { Mergers between member firms within business } \\
\text { groups }\end{array}$} \\
\hline & & With no stock exchange & With a stock exchange \\
\hline-2 & $\begin{array}{c}0.070 \\
(0.029)\end{array}$ & $\begin{array}{l}0.014 \\
(0.016)\end{array}$ & $\begin{array}{c}0.001 \\
(0.004)\end{array}$ \\
\hline-1 & $\begin{array}{c}0.154^{* * *} \\
\left(0.170^{* * *}\right)\end{array}$ & $\begin{array}{l}0.012 \\
(0.002)\end{array}$ & $\begin{array}{c}0.027^{* * *} \\
\left(0.026^{* * *}\right)\end{array}$ \\
\hline No. of observations & 13 & 43 & 87 \\
\hline \multicolumn{4}{|c|}{$\begin{array}{l}\text { Earnings management (discretionary accruals) is estimated using the cross-sectional adaptation of the } \\
\text { modified Jones model. Nondiscretionary accruals are subtracted from realized accruals to calculate } \\
\text { (matching firm-uncontrolled) discretionary accruals. The discretionary accruals for a matching firm are } \\
\text { chosen based on industry and prior-year performance from those for a merger firm. The matching firm- } \\
\text { controlled discretionary accruals are used as a measure of earnings management. Year }-1 \text { is one year prior to } \\
\text { the merger announcement. }{ }^{* * *} \text {, and }{ }^{* * *} \text { denote significance at the } 0.1,0.05 \text {, and } 0.01 \text { levels, respectively. }\end{array}$} \\
\hline
\end{tabular}


Table 4

Regressions of earnings management of acquiring firms in member-firm mergers with a stock exchange on characteristics of acquiring and target firms

Panel A: Using the continuous experimental variables

\begin{tabular}{|c|c|c|c|c|c|c|}
\hline \multirow[t]{2}{*}{ Independent variable } & \multicolumn{6}{|c|}{$\begin{array}{c}\begin{array}{c}\text { Dependent variable }=\text { EARNINGS MANAGEMENT of the acquiring firm } \\
\text { in year }-1\end{array}\end{array}$} \\
\hline & $(1)$ & $(2)$ & (3) & (4) & $(5)$ & $(6)$ \\
\hline \multicolumn{7}{|l|}{ Experimental variables } \\
\hline AHOLDING & $\begin{array}{c}0.001^{* *} \\
(2.53)\end{array}$ & & & & & \\
\hline AHOLDING $\times$ ASIZE (a) & & $\begin{array}{c}0.001^{* * *} \\
(2.79)\end{array}$ & & & & \\
\hline THOLDING & $\begin{array}{c}-0.001^{* * *} \\
(-2.87)\end{array}$ & & & & & \\
\hline THOLDING $\times$ TSIZE $(b)$ & & $\begin{array}{c}-0.001^{* * *} \\
(-2.77)\end{array}$ & & & & \\
\hline AHOLDING/THOLDING & & & $\begin{array}{l}0.049^{* * *} \\
(2.76)\end{array}$ & $\begin{array}{c}0.051^{* * *} \\
(2.87)\end{array}$ & & \\
\hline$a / b$ & & & & & $\begin{array}{l}0.054^{* * *} \\
(2.81)\end{array}$ & $\begin{array}{c}0.055^{* * *} \\
(2.91)\end{array}$ \\
\hline LARGE & & & & $\begin{array}{l}0.033^{*} \\
(1.78)\end{array}$ & & $\begin{array}{l}0.031 \\
(1.50)\end{array}$ \\
\hline \multicolumn{7}{|c|}{ Acquiring firm characteristics } \\
\hline INSTITUTION & $\begin{array}{l}0.000 \\
(0.50)\end{array}$ & $\begin{array}{l}0.000 \\
(0.67)\end{array}$ & $\begin{array}{l}0.000 \\
(0.94)\end{array}$ & $\begin{array}{l}0.000 \\
(0.27)\end{array}$ & $\begin{array}{l}0.000 \\
(0.61)\end{array}$ & $\begin{array}{l}0.000 \\
(0.11)\end{array}$ \\
\hline FOREIGN & $\begin{array}{l}0.001^{*} \\
(1.80)\end{array}$ & $\begin{array}{l}0.001^{*} \\
(1.84)\end{array}$ & $\begin{array}{c}0.001^{* *} \\
(2.00)\end{array}$ & $\begin{array}{l}0.001^{*} \\
(1.76)\end{array}$ & $\begin{array}{l}0.001^{*} \\
(1.68)\end{array}$ & $\begin{array}{l}0.001 \\
(1.50)\end{array}$ \\
\hline COA & $\begin{array}{c}-0.673^{* * *} \\
(-7.27)\end{array}$ & $\begin{array}{c}-0.656^{* * *} \\
(-7.12)\end{array}$ & $\begin{array}{c}-0.688^{* * *} \\
(-7.24)\end{array}$ & $\begin{array}{c}-0.667^{* * *} \\
(-7.10)\end{array}$ & $\begin{array}{c}-0.651^{* * *} \\
(-6.19)\end{array}$ & $\begin{array}{r}-0.646^{* *} \\
(-6.21)\end{array}$ \\
\hline$R O A$ & $\begin{array}{c}0.326^{* * *} \\
(2.90)\end{array}$ & $\begin{array}{c}0.323^{* * *} \\
(2.88)\end{array}$ & $\begin{array}{c}0.342^{* * *} \\
(3.00)\end{array}$ & $\begin{array}{c}0.303^{* * *} \\
(2.65)\end{array}$ & $\begin{array}{l}0.245^{*} \\
(1.70)\end{array}$ & $\begin{array}{l}0.239^{*} \\
(1.68)\end{array}$ \\
\hline$D E B T$ & $\begin{array}{c}-0.142^{* *} \\
(-2.52)\end{array}$ & $\begin{array}{c}-0.139^{* *} \\
(-2.47)\end{array}$ & $\begin{array}{c}-0.124^{* *} \\
(-2.17)\end{array}$ & $\begin{array}{c}-0.143^{* *} \\
(-2.51)\end{array}$ & $\begin{array}{l}-0.120^{*} \\
(-1.71)\end{array}$ & $\begin{array}{c}-0.145^{* *} \\
(-2.03)\end{array}$ \\
\hline \multicolumn{7}{|l|}{ Target firm characteristics } \\
\hline$R O A$ & $\begin{array}{l}-0.003 \\
(-0.07)\end{array}$ & $\begin{array}{l}0.005 \\
(0.11)\end{array}$ & $\begin{array}{c}0.002 \\
(0.005)\end{array}$ & $\begin{array}{l}0.000 \\
(0.02)\end{array}$ & $\begin{array}{l}0.001 \\
(0.02)\end{array}$ & $\begin{array}{l}-0.001 \\
(-0.03)\end{array}$ \\
\hline$D E B T$ & $\begin{array}{l}-0.018 \\
(-0.54)\end{array}$ & $\begin{array}{l}-0.014 \\
(-0.45)\end{array}$ & $\begin{array}{l}-0.017 \\
(-0.52)\end{array}$ & $\begin{array}{l}-0.033 \\
(-0.99)\end{array}$ & $\begin{array}{l}-0.017 \\
(-0.43)\end{array}$ & $\begin{array}{l}-0.033 \\
(-0.81)\end{array}$ \\
\hline Intercept & $\begin{array}{c}0.149^{* * *} \\
(3.02)\end{array}$ & $\begin{array}{c}0.139^{* * *} \\
(2.96)\end{array}$ & $\begin{array}{l}0.082^{*} \\
(1.92)\end{array}$ & $\begin{array}{c}0.094^{* *} \\
(2.22)\end{array}$ & $\begin{array}{l}0.083^{*} \\
(1.74)\end{array}$ & $\begin{array}{c}0.098^{* *} \\
(2.04)\end{array}$ \\
\hline F-value & 15.02 & 15.20 & 15.37 & 14.67 & 8.65 & 8.20 \\
\hline Adjusted-R ${ }^{2}$ & 0.674 & 0.676 & 0.659 & 0.671 & 0.530 & 0.541 \\
\hline No. of observations & 70 & 70 & 69 & 69 & 69 & 69 \\
\hline
\end{tabular}


Panel B: Using the dummy experimental variables

\begin{tabular}{|c|c|c|c|c|c|}
\hline \multirow{2}{*}{$\begin{array}{c}\text { Independent } \\
\text { variable }\end{array}$} & \multicolumn{5}{|c|}{$\begin{array}{l}\text { Dependent variable }=\text { EARNINGS MANAGEMENT of the acquiring firm } \\
\text { in year }-1\end{array}$} \\
\hline & (1) & (2) & (3) & (4) & (5) \\
\hline \multicolumn{6}{|l|}{ Experimental variable } \\
\hline D_AHOLDING (a) & $\begin{array}{l}0.002 \\
(0.12)\end{array}$ & & & $\begin{array}{l}0.006 \\
(0.37)\end{array}$ & $\begin{array}{l}0.038^{*} \\
(1.69)\end{array}$ \\
\hline D_THOLDING (b) & & $\begin{array}{c}-0.035^{* *} \\
(-2.14)\end{array}$ & & $\begin{array}{c}-0.037^{* *} \\
(-2.15)\end{array}$ & $\begin{array}{l}-0.016 \\
(0.80)\end{array}$ \\
\hline$a / b$ & & & $\begin{array}{c}0.037^{* *} \\
(2.25)\end{array}$ & & $\begin{array}{l}0.056^{* *} \\
(2.04)\end{array}$ \\
\hline \multicolumn{6}{|c|}{ Acquiring firm characteristics } \\
\hline COA & $\begin{array}{c}-0.642^{* * *} \\
(-6.58)\end{array}$ & $\begin{array}{c}-0.663^{* * *} \\
(-6.89)\end{array}$ & $\begin{array}{c}-0.635^{* * *} \\
(-6.78)\end{array}$ & $\begin{array}{c}-0.662^{* * *} \\
(-6.81)\end{array}$ & $\begin{array}{l}-0.625 \\
(-6.49)\end{array}$ \\
\hline$R O A$ & $\begin{array}{c}0.477^{* * *} \\
(4.38)\end{array}$ & $\begin{array}{c}0.459^{* * *} \\
(4.30)\end{array}$ & $\begin{array}{c}0.454^{* *} \\
(4.31)\end{array}$ & $\begin{array}{c}0.458^{* * *} \\
(4.26)\end{array}$ & $\begin{array}{c}0.431^{* * *} \\
(4.09)\end{array}$ \\
\hline$D E B T$ & $\begin{array}{l}-0.060 \\
(-1.12)\end{array}$ & $\begin{array}{l}-0.088 \\
(-1.62)\end{array}$ & $\begin{array}{l}-0.064 \\
(-1.24)\end{array}$ & $\begin{array}{l}-0.089 \\
(-1.63)\end{array}$ & $\begin{array}{c}-0.082^{* * *} \\
(-1.54)\end{array}$ \\
\hline \multicolumn{6}{|c|}{ Target firm characteristics } \\
\hline$R O A$ & $\begin{array}{l}0.024 \\
(0.54)\end{array}$ & $\begin{array}{l}0.015 \\
(0.35)\end{array}$ & $\begin{array}{l}0.037 \\
(0.84)\end{array}$ & $\begin{array}{l}0.012 \\
(0.27)\end{array}$ & $\begin{array}{l}0.021 \\
(0.49)\end{array}$ \\
\hline$D E B T$ & $\begin{array}{l}-0.027 \\
(-0.12)\end{array}$ & $\begin{array}{l}-0.029 \\
(-0.86)\end{array}$ & $\begin{array}{l}-0.041 \\
(-1.26)\end{array}$ & $\begin{array}{l}-0.027 \\
(-0.77)\end{array}$ & $\begin{array}{l}-0.032 \\
(-0.95)\end{array}$ \\
\hline Intercept & $\begin{array}{l}0.082^{*} \\
(1.91)\end{array}$ & $\begin{array}{l}0.123^{* *} \\
(2.57)\end{array}$ & $\begin{array}{c}0.107^{* *} \\
(2.51)\end{array}$ & $\begin{array}{c}0.127^{* *} \\
(2,58)\end{array}$ & $\begin{array}{c}0.148^{* * *} \\
(3.01)\end{array}$ \\
\hline F-value & 16.22 & 17.74 & 18.24 & 15.32 & 14.79 \\
\hline Adjusted- $\mathrm{R}^{2}$ & 0.603 & 0.633 & 0.633 & 0.628 & 0.646 \\
\hline No. Observations & 69 & 69 & 69 & 69 & 69 \\
\hline
\end{tabular}

EARNINGS MANAGEMENT = Earnings management (discretionary accruals in year -1) is estimated using the cross-sectional adaptation of the modified Jones model. Nondiscretionary accruals are subtracted from realized accruals to calculate (matching firm-uncontrolled) discretionary accruals. The discretionary accruals for a matching firm are chosen based on industry and prior-year performance from those for a merger firm. The matching firm-controlled discretionary accruals are used as a measure of earnings management; AHOLDING = the controlling owner's holdings in the acquiring firm; ASIZE = Log (book value of the acquiring firm); $L A R G E=1$ if the group to which a firm belongs is among the 30 largest groups, 0 otherwise; INSTITUTION = holdings by financial institutions; FOREIGN = holdings by foreign investors; THOLDING = the controlling owner's holdings in the target firm; TSIZE = Log (book value of target firm); COA = cash flow from operation/assets; $R O A=$ income/assets; $D E B T=$ debt/assets; $D \_A H O L D I N G$ is 1 if the controlling owner's holdings in the acquiring firm are greater than or equal to the median of the sample, and 0 otherwise; D_THOLDING is 1 if the controlling owner's holdings in the target firm are equal to or greater than the median of the sample, and 0 otherwise. T-values are in parentheses. ${ }^{*},{ }^{* *}$, and ${ }^{* * *}$ denote significance at the $0.1,0.05$, and 0.01 level, respectively. 
Table 5

Regressions of earnings management of target firms in member-firm mergers with a stock exchange on characteristics of acquiring and target firms

\begin{tabular}{|c|c|c|c|c|c|c|}
\hline \multirow[t]{2}{*}{ Independent variable } & \multicolumn{6}{|c|}{$\begin{array}{c}\text { Dependent variable }=\text { EARNINGS MANAGEMENT of the target firm } \\
\text { in year }-1\end{array}$} \\
\hline & $(1)$ & $(2)$ & (3) & (4) & (5) & (6) \\
\hline \multicolumn{7}{|l|}{ Experimental variable } \\
\hline AHOLDING & $\begin{array}{l}-0.001^{*} \\
(-1.68)\end{array}$ & & & & & \\
\hline AHOLDING $\times$ ASIZE (a) & & $\begin{array}{l}-0.001^{*} \\
(-1.71)\end{array}$ & & & & \\
\hline THOLDING & $\begin{array}{c}0.001^{* *} \\
(2.34)\end{array}$ & & & & & \\
\hline THOLDING $\times$ TSIZE (b) & & $\begin{array}{c}0.001^{* *} \\
(2.50)\end{array}$ & & & & \\
\hline AHOLDING/THOLDING & & & $\begin{array}{l}-0.010 \\
(-1.02)\end{array}$ & $\begin{array}{l}-0.010 \\
(-1.01)\end{array}$ & & \\
\hline$a / b$ & & & & & $\begin{array}{l}-0.013 \\
(-1.32)\end{array}$ & $\begin{array}{l}-0.013 \\
(-1.32)\end{array}$ \\
\hline Large & & & & $\begin{array}{l}-0.011 \\
(-0.62)\end{array}$ & & $\begin{array}{l}-0.010 \\
(-0.57)\end{array}$ \\
\hline \multicolumn{7}{|l|}{ Target firm characteristics } \\
\hline COA & $\begin{array}{c}-0.879^{* * *} \\
(-14.69)\end{array}$ & $\begin{array}{l}-0.874^{\text {*** }} \\
(-14.57)\end{array}$ & $\begin{array}{l}-0.832^{* * *} \\
(-13.55)\end{array}$ & $\begin{array}{l}-0.832^{* * *} \\
(-13.46)\end{array}$ & $\begin{array}{l}-0.799^{* * *} \\
(-12.36)\end{array}$ & $\begin{array}{l}-0.796^{\text {*** }} \\
(-12.16)\end{array}$ \\
\hline$R O A$ & $\begin{array}{c}0.777^{* * *} \\
(8.29)\end{array}$ & $\begin{array}{c}0.772^{* * *} \\
(8.23)\end{array}$ & $\begin{array}{c}0.757^{* * *} \\
(7.54)\end{array}$ & $\begin{array}{c}0.752^{* * *} \\
(7.43)\end{array}$ & $\begin{array}{c}0.707^{* * * *} \\
(6.69)\end{array}$ & $\begin{array}{c}0.699^{* * *} \\
(6.51)\end{array}$ \\
\hline$D E B T$ & $\begin{array}{l}0.017 \\
(0.37)\end{array}$ & $\begin{array}{l}0.020 \\
(0.44)\end{array}$ & $\begin{array}{c}0.006 \\
(0.13)\end{array}$ & $\begin{array}{l}0.013 \\
(0.26)\end{array}$ & $\begin{array}{l}0.024 \\
(0.45)\end{array}$ & $\begin{array}{l}0.030 \\
(0.54)\end{array}$ \\
\hline \multicolumn{7}{|c|}{ Acquiring firm characteristics } \\
\hline$R O A$ & $\begin{array}{l}0.196^{* *} \\
(2.49)\end{array}$ & $\begin{array}{c}0.198^{* *} \\
(2.51)\end{array}$ & $\begin{array}{l}0.114 \\
(1.29)\end{array}$ & $\begin{array}{l}0.135 \\
(1.42)\end{array}$ & $\begin{array}{l}0.123 \\
(1.08)\end{array}$ & $\begin{array}{l}0.135 \\
(1.17)\end{array}$ \\
\hline$D E B T$ & $\begin{array}{c}0.085^{* *} \\
(2.04)\end{array}$ & $\begin{array}{c}0.084^{* *} \\
(2.03)\end{array}$ & $\begin{array}{l}0.049 \\
(1.07)\end{array}$ & $\begin{array}{l}0.057 \\
(1.19)\end{array}$ & $\begin{array}{l}0.071 \\
(1.37)\end{array}$ & $\begin{array}{l}0.083 \\
(1.48)\end{array}$ \\
\hline Intercept & $\begin{array}{l}-0.030 \\
(-0.74)\end{array}$ & $\begin{array}{l}-0.034 \\
(-0.86)\end{array}$ & $\begin{array}{l}0.011 \\
(0.26)\end{array}$ & $\begin{array}{l}0.007 \\
(0.17)\end{array}$ & $\begin{array}{l}-0.015 \\
(-0.35)\end{array}$ & $\begin{array}{l}-0.021 \\
(-0.47)\end{array}$ \\
\hline F-value & $28.62^{* * *}$ & $29.11^{* * *}$ & $29.89^{* * *}$ & $25.89^{* * *}$ & $29.71^{* * *}$ & $25.16^{* * *}$ \\
\hline Adjusted-R ${ }^{2}$ & 0.824 & 0.827 & 0.774 & 0.772 & 0.755 & 0.751 \\
\hline No. of observations & 60 & 60 & 60 & 60 & 60 & 60 \\
\hline
\end{tabular}

EARNINGS MANAGEMENT = Earnings management (discretionary accruals in year -1) is estimated using the cross-sectional adaptation of the modified Jones model. Nondiscretionary accruals are subtracted from realized accruals to calculate (matching firm-uncontrolled) discretionary accruals. The discretionary accruals for a matching firm are chosen based on industry and prior-year performance from those for a merger firm. The matching firm-controlled discretionary accruals are used as a measure of earnings management; ASIZE $=$ Log (book value of the acquiring firm); $L A R G E=1$ if the group to which a firm belongs is among the 30 largest groups, 0 otherwise; THOLDING = the controlling owner's holdings in the target firm; TSIZE $=$ Log (book value of target firm); $C O A=$ cash flow from operation/assets; $R O A=$ income/assets; $D E B T=\operatorname{debt} /$ assets. Tvalues are in parentheses. ${ }^{*},{ }^{* *}$, and ${ }^{* * *}$ denote significance at the $0.1,0.05$, and 0.01 level, respectively. 
Table 6

The mean (median) cumulative abnormal returns (CARs) to merger announcements by merger type

\begin{tabular}{cccc}
\hline & & \multicolumn{2}{c}{$\begin{array}{c}\text { Mergers between member firms within } \\
\text { business groups }\end{array}$} \\
\cline { 3 - 4 } Days & $\begin{array}{c}\text { Mergers between } \\
\text { independent firms }\end{array}$ & With no stock exchange $\quad$ With a stock exchange \\
& 0.015 & 0.016 & $0.018^{* *}$ \\
$(-1,1)$ & $(-0.003)$ & $(0.008)$ & $\left(0.009^{* *}\right)$ \\
& -0.006 & $0.024^{*}$ & $0.018^{* *}$ \\
$(-2,2)$ & $(-0.005)$ & $(0.011)$ & $\left(0.012^{*}\right)$ \\
\hline
\end{tabular}

Abnormal returns are estimated using the market model. The market model parameters are estimated using $(-135,-10)$ days prior to a merger announcement. ${ }^{* * *}$, , and ${ }^{* * *}$ denote significance at the $0.1,0.05$, and 0.01 levels, respectively. 
Table 7

The relationship between earnings management and the announcement period cumulative abnormal returns (CARs) using member-firm mergers with a stock exchange

Independent variable

Dependent variable $=\mathrm{CAR}(-1,1)$

\begin{tabular}{|c|c|c|c|c|}
\hline & (1) & (2) & (3) & (4) \\
\hline Intercept & $\begin{array}{l}-0.024 \\
(-0.82)\end{array}$ & $\begin{array}{l}-0.018 \\
(-0.58)\end{array}$ & $\begin{array}{l}0.117 \\
(0.65)\end{array}$ & $\begin{array}{l}0.104 \\
(0.65)\end{array}$ \\
\hline EARNINGS MANAGEMENT & $\begin{array}{c}-0.374^{* * *} \\
(-3.88)\end{array}$ & $\begin{array}{c}-0.449^{* * * *} \\
(3.62)\end{array}$ & $\begin{array}{c}-0.403^{* * *} \\
(-3.07)\end{array}$ & $\begin{array}{c}-0.402^{* * *} \\
(-3.06)\end{array}$ \\
\hline AHOLDING & $\begin{array}{l}0.000 \\
(0.30)\end{array}$ & & $\begin{array}{l}0.000 \\
(0.21)\end{array}$ & \\
\hline$A H O L D I N G \times A S I Z E$ & & $\begin{array}{l}0.000 \\
(0.28)\end{array}$ & & $\begin{array}{l}0.000 \\
(0.22)\end{array}$ \\
\hline ASIZE & & & $\begin{array}{l}-0.011 \\
(-1.13)\end{array}$ & $\begin{array}{l}-0.011 \\
(-1.14)\end{array}$ \\
\hline THOLDING & $\begin{array}{l}-0.000 \\
(-0.22)\end{array}$ & & $\begin{array}{l}-0.000 \\
(-0.29)\end{array}$ & \\
\hline THOLDING $\times$ TSIZE & & $\begin{array}{l}-0.000 \\
(-0.11)\end{array}$ & & $\begin{array}{l}-0.000 \\
(-0.21)\end{array}$ \\
\hline TSIZE & & & $\begin{array}{l}0.004 \\
(0.59)\end{array}$ & $\begin{array}{l}0.005 \\
(0.72)\end{array}$ \\
\hline F-value & 2.21 & 2.13 & 1.91 & 1.91 \\
\hline Adjusted- $R^{2}$ & 0.186 & 0.190 & 0.179 & 0.178 \\
\hline No. of observations & 70 & 70 & 70 & 70 \\
\hline
\end{tabular}

Abnormal returns are estimated using the market model. The market model parameters are estimated using $(-135,-10)$ days prior to a merger announcement. EARNINGS MANAGEMENT = Earnings management (discretionary accruals in year -1) is estimated using the cross-sectional adaptation of the modified Jones model. Nondiscretionary accruals are subtracted from realized accruals to calculate (matching firmuncontrolled) discretionary accruals. The discretionary accruals for a matching firm are chosen based on industry and prior-year performance from those for a merger firm. The matching firm-controlled discretionary accruals ("discretionary accruals") are used as a measure of earnings management; AHOLDING = the controlling owner's holdings in the acquiring firm; THOLDING = the controlling owner's holdings in the target firm; $A S I Z E=\log$ (book value of the acquiring firm); TSIZE $=\log$ (book value of target firm). Tvalues are in parentheses. ${ }^{* *}$, and ${ }^{* * *}$ denote significance at the $0.1,0.05$, and 0.01 , respectively. 
Table 8

Matching firm-controlled long-run buy-and-hold abnormal market returns (BHAR) of acquiring firms by merger type

\begin{tabular}{|c|c|c|c|}
\hline \multirow[b]{2}{*}{ Months } & \multirow{2}{*}{$\begin{array}{l}\text { Mergers between } \\
\text { independent firms }\end{array}$} & \multicolumn{2}{|c|}{$\begin{array}{c}\text { Mergers between member firms within business } \\
\text { groups }\end{array}$} \\
\hline & & With no stock exchange & With a stock exchange \\
\hline$(-12,-1)$ & $\begin{array}{l}-0.048 \\
(-0.134)\end{array}$ & $\begin{array}{l}-0.037 \\
(-0.054)\end{array}$ & $\begin{array}{l}0.390^{* *} \\
(0.035)\end{array}$ \\
\hline$(1,12)$ & $\begin{array}{c}0.031 \\
(0.127)\end{array}$ & $\begin{array}{c}0.023 \\
(-0.077)\end{array}$ & $\begin{array}{l}-0.163^{*} \\
(-0.059)\end{array}$ \\
\hline$(1,36)$ & $\begin{array}{l}-0.067 \\
(-0.042)\end{array}$ & $\begin{array}{c}-0.178 \\
(-0.151)\end{array}$ & $\begin{array}{l}-0.307^{*} \\
(-0.119)\end{array}$ \\
\hline No. of observations & 18 & 39 & 91 \\
\hline \multicolumn{4}{|c|}{$\begin{array}{l}\text { Monthly return data are used to calculate matching-firm-controlled buy-and-hold abnormal returns (BHAR). } \\
\text { BHAR of the acquiring firm is calculated following the method proposed by Baber and Lyon (1997). } \\
\text { Matching firms are found first by matching by size and then by the market-to-book ratio. More specifically, } \\
\text { we first identify non-merger firms the size of which is between } 70 \% \text { and } 130 \% \text { of the sample firm in year - } 1 \text {. } \\
\text { Then, among these firms we select the firm with the closest market-to-book ratio as the matching firm. , , } \\
\text { and }{ }^{* * *} \text { denote significance at the } 0.1,0.05 \text {, and } 0.01 \text { level, respectively. }\end{array}$} \\
\hline
\end{tabular}




\section{Appendix A: Method for Measuring Discretionary Accruals}

Dechow, Sloan, and Sweeney (1995) and Kothari, Leone, and Wasley (2004) have demonstrated that the modified Jones (1991) model performs best among the various discretionary accruals models. This model has been adopted in many studies, including Louis (2004), among others. Following these studies, for each year in the test period we measure the coefficients of the accrual models by estimating the following regressions for non-merger firms that operate in the same industry as the firms in the merger (to the first two digits of the industry code used in the KISFAS database) $::^{26}$

$$
A C_{i t} / T A_{i t-1}=\beta_{0} / T A_{i t-1}+\beta_{1}\left(\Delta R E V_{i t}-\triangle R E C_{i t}\right) / T A_{i t-1}+\beta_{2} P P E_{i t} / T A_{i t-1}+\varepsilon_{i t},
$$

where $\mathrm{AC}_{\mathrm{it}}$ represents accruals in year $t$ for firm $i$; $\mathrm{TA}_{\mathrm{it}-1}$ represents total assets (KIS-FAS \#115000) in year $t-1$ for firm $i ; \Delta \mathrm{REV}_{\text {it }}$ represents revenues (\#121000) in year $t$ less revenues in year $t-1$ for firm $i$ (i.e., change in revenues); $\Delta \mathrm{REC}_{\mathrm{it}}$ represents receivables (\#111150) in year $t$ less receivables in year $t-1$ for firm $i$ (i.e., change in receivables); and $\mathrm{PPE}_{\mathrm{it}}$ represents gross amount of property, plant, and equipments (\#114000). We scale all variables in regression (a1) by total assets in year $t-1$ to reduce potential heteroskedasticity. This cross-sectional regression is re-estimated for each year and industry.

We then compute nondiscretionary accruals (NDAC) for the sample firms as follows:

${ }^{26}$ Following previous research (e.g., Jones, 1991; Gaver, Gaver, and Austin, 1995; Sloan, 1996), we estimate accruals in year $t$ as the change in current assets (KIS-FAS \#112000) other than cash (\#111100) and short-term investments (\#111220) in two consecutive years ending in year $t$ less the change in current liabilities (\#116000) other than current portion of long-term debt (\#115190) in two consecutive years ending in year $t$ less depreciation, amortization, and depletion (\#161211+\#161212+\#161249) in year $t$. 


$$
N D A C_{j t}=b_{0} / T A_{j t-1}+b_{1}\left(\Delta R E V_{j t}-\Delta R E C_{j t}\right) / T A_{j t-1}+b_{2} P P E_{j t} T A_{j t-1},
$$

where $b_{0}, b_{1}$, and $b_{2}$ are the estimated coefficients from regressions (a1).

Discretionary accruals (DAC) are computed as the difference between realized accruals scaled by the prior year's total assets and NDAC. Following Kothari, Leone, and Wasley (2004), we subtract the DAC for a matching firm from that for a sample firm where a non-merger firm is matched to each sample firm by industry (two-digit industry code) and asset-scaled net income (i.e., $\left.\mathrm{ROA}_{\mathrm{it}}\right)$. We interpret this matching firm-controlled discretionary accruals estimate as a proxy for accruals manipulation. 